\title{
The Intonation of Polar Questions in North American ("Heritage") Icelandic
}

\author{
Nicole Dehé \\ Universität Konstanz
}

\begin{abstract}
Using map task data, this paper investigates the intonation of polar questions in North American (heritage) Icelandic, and compares it to the intonation of polar questions in Icelandic as spoken in Iceland and in North American English as spoken in Manitoba, Canada. The results show that intonational features typical of Icelandic polar questions are present to a considerable extent in heritage Icelandic. Furthermore, intonational features typical of North American English polar questions can frequently be observed in heritage Icelandic, too. In addition, there is a tendency for intonational features typical of Icelandic polar questions to show up in North American English polar questions produced by speakers of heritage Icelandic more often than in North American English polar questions produced by speakers without Icelandic heritage. Focusing on intonation, the present study adds to the evidence for (bidirectional) prosodic interference between a heritage language (here moribund Icelandic) and the dominant language (here North American English).*
\end{abstract}

\footnotetext{
* The empirical work presented here was partly supported by a Snorri Sturluson Fellowship from the Árni Magnússon Institute for Icelandic Studies to the author, which I gratefully acknowledge. I am particularly grateful to Höskuldur Práinsson, without whom the recordings in Canada would not have happened. In Iceland, along with Höskuldur, I received indispensable support from Herdís P. Sigurðardóttir, Jóhannes Gísli Jónsson, Jóna Vilhelmína Héðinsdóttir, Kristján Árnason, Margrét Pálsdóttir, Peter Weiss, and Pórhallur Eypórsson. Thanks are further due to all students who helped with the recordings and transcriptionsamong them Hólmfríður Helga Sigurðardóttir, Ingunn Hreinberg Indriðadóttir, Nanna Kristjánsdóttir, and Porbjörg Porvaldsdóttir - as well as to all participants of the map task study. The maps used in the map task were designed in collaboration with Porbjörg Porvaldsdóttir, who also drew the maps. I thank Bettina Braun, Tanja Kupisch, and Christiane Ulbrich for valuable comments and discussion, and Bettina Braun and Sophie Egger for sharing their statistical expertise. Further thanks go to two anonymous JGL reviewers for their comments.
} 
Keywords: Icelandic, North American Icelandic, heritage language, intonation, polar questions, question intonation

\section{Introduction.}

North American Icelandic (NAmIce) is a heritage language (HL) still spoken in certain parts of the US and Canada (for example, Bessason 1967; Arnbjörnsdóttir 2006, 2015; Johannessen \& Salmons 2015; Thráinsson 2016). Today's speakers of NAmIce are descendants of Icelandic immigrants to North America, who settled mainly in areas of Manitoba and Saskatchewan in Canada and North Dakota in the United States between 1872 and 1914 (Bessason 1967, Arnbjörnsdóttir 2006, 2015). In other words, today's NAmIce speakers are typically third or fourth generation speakers. In 2014, when the present study was carried out, NAmIce speakers were 77 years old on average (see also Thráinsson 2016). Speakers of NAmIce typically grew up with Icelandic as their first and only language (L1) until the age of 5 or 6 (school entry), when their second language, North American English (NAmEngl; L2), became the dominant and thus primary language due to school policy at the time. Many grew up speaking NAmIce to first generation immigrants (that is, their grandparents). Today, their dominant language is NAmEngl - and it has been for decades - and NAmIce is only used occasionally, if it is used at all (see section 3.2). They generally have little or no contact with native speakers of present-day Icelandic spoken in Iceland (IceIce). Arnbjörnsdóttir (2006) reports that even back in 1986, when her data were gathered, very little NAmIce was spoken even on the occasion of Icelandic social events. Present day speakers of NAmIce have typically not received formal instruction in either variety of Icelandic, including instruction or practice in reading. NAmIce thus conforms to the definition of HLs in North America put forward in Benmamoun et al. 2013 and Montrul 2016: It is a language other than NAmEngl (and French in Canada) spoken by immigrants and their descendants; its typical speaker is an early bilingual who grew up hearing and speaking their L1 (NAmIce) and L2 (NAmEngl) sequentially in early childhood, and for whom NAmEngl became dominant at school entry. Arnbjörnsdóttir (2006) and Johannessen \& Salmons (2015) agree that it is remarkable that NAmIce has survived comparatively well until today, given that there has been no continuation of immigration from 1914 until recently and little to no travel to and from Iceland between 1914 and 1975. 
The present paper focuses on the intonation of NAmIce in production, more specifically, on the intonation of polar questions (PQs; also known as yes/no-questions). NAmIce PQs are compared to PQs in IceIce and to PQs in NAmEngl as spoken in Manitoba. PQs are interesting because while their syntax is very similar in the two languages - NAmEngl and IceIce - their intonation is very different (see section 2 below for details). The study of the intonation of PQs in NAmIce thus contributes i) to the documentation of the intonational grammar of NAmIce, as well as ii) more generally to the study of maintenance and interference effects in intonation, using the case of the HL NAmIce in contact with the dominant language NAmEngl.

While documentation of the intonation of the NAmIce spoken by the immigrants to Manitoba does not exist, I assume that it was not strikingly different from the language of the IceIce speakers included in this study. The following points lead to this assumption. First, IceIce has generally undergone fewer changes in its history than other languages. Compared with the other Scandinavian languages, it is the most conservative and has the fewest changes in structure and lexicon compared with Old Norse (Haugen 1984, Thráinsson 1994). Henriksen \& van der Auwera (1994:7) refer to it as "a unique case of linguistic continuity." Notably, the long Danish rule (1380-1918) in the history of Iceland did not have a "lasting effect on the Icelandic culture or language" (Arnbjörnsdóttir 2006:33). According to Haugen (1984:35), grammatical and lexical conservatism was even a source of pride in the 19th century. Arnbjörnsdóttir (2006:37) maintains that "[f]rom the beginning of the last century until today, modern Icelandic ... has only undergone minor changes."

Second, most of the NAmIce speakers tested here grew up and spoke NAmIce with first generation immigrants. Immigrants to Manitoba, Arnbjörnsdóttir (2006:33) argues, brought with them "their wish to retain their old customs and own culture and language," and actions were taken to preserve the Icelandic language (see Arnbjörnsdóttir 2006, chapter 2). Third, the speakers of IceIce used for comparison are of the same age as the NAmIce speakers, and all effort has been made to ensure that they are from the same regions of Iceland as the immigrants. Unlike many other languages, IceIce is generally known for little regional variation in intonation and is generally said to have only "minimal linguistic differences ... among different regional varieties of Icelandic" 
(Arnbjörnsdóttir 2006:20; see also Haugen 1984). ${ }^{1}$ Phonological variation in IceIce is documented in Thráinsson \& Árnason 1992, but that study does not include prosodic/intonational variation. IceIce clearly does not have dialects to the same extent as some of its relatives such as Faroese, Norwegian, and German (see, among others, Kügler 2004 and Peters 2006 for regional intonational variation in German). It has been noted, for example, that different source dialects going back to different regions of origin of German-speaking settlers have to be taken into account for the study of Pennsylvania German (PG; see, for instance, Huffines 1986 for intonation). This is different from the situation one finds for NAmIce. Moreover, while most regions in Iceland saw emigration to North America, many immigrants came from the north or northeast of Iceland because those regions were hit hardest by the natural disasters that led to poverty, which, in turn, led to emigration (Arnbjörnsdóttir 2006). For example, of a total of 14,268 emigrants from Iceland to North America between 1870 and 1914, only 294 came from Reykjavík, while taken together, 4,391 emigrants (31\%) came from the three districts of Skagafjarðarsýsla, Eyjafjarðarsýsla, and bingeyjarsýsla adjacent to each other in the north of Iceland, and 435 emigrants came from Ísafjarðarsýsla in the West fjords (numbers taken from Arnbjörnsdóttir 2006:27, whose source is Kristinsson 1983). ${ }^{2}$ Crucially, the IceIce informants whose data were used for comparison in the present study also came from these districts (see section 3.2). ${ }^{3}$

\footnotetext{
${ }^{1}$ Árnason (2011:324) maintains that "speakers from the northern parts of Iceland are more likely to use High boundary tones" in declarative sentences than speakers of other parts of Iceland (see also Árnason 2005:479). However, geographic variation in IceIce intonation has never been studied systematically. In my own map task data recorded in three regions in Iceland (see section 3.2 below), I have not yet observed any obvious differences between varieties of IceIce.

${ }^{2}$ Note that the number of Icelanders who emigrated to North America at the time may actually have been close to 20,000, but sources disagree (see Arnbjörnsdóttir 2006:25).

${ }^{3}$ Notice also that another 5,156 emigrants (36\%) came from three districts in north Iceland, which are adjacent on the east and west to the districts mentioned above and from which the IceIce speakers were recruited. If anything, intonational variation is reported between the north and south (capital region) of Iceland (Árnason 2005, 2011), which would thus not be relevant in the present context.
} 
Finally, many of the NAmIce speakers included in this study grew up with first generation immigrants, typically their grandparents. I therefore assume that the IceIce spoken by speakers of about the same age as the heritage speakers recorded in Manitoba, and from exactly the same regions as a third of the immigrants, is as close as one can currently get to an appropriate baseline for present-day NAmIce. Arnbjörnsdóttir (2006) reports two general types of changes in the 1986 NAmIce as compared to the immigrants' language: i) lexical and grammatical borrowings from NAmEngl, and ii) leveling and simplification due to language attrition and reduced functions of the language (see Arnbjörnsdóttir 2006, 2015 for details).

Earlier descriptions of NAmIce do not include a description of its intonation. For example, the studies by Stefánsson (1903) and Bessason (1967) focus on lexical borrowings, their morphology and pronunciation as well as shifts in meaning, and, in the case of Bessason 1967, also on proper nouns and place names. The main emphasis in Arnbjörnsdóttir 2006, which is based on recordings made in 1986, is on the vowel system of NAmIce, but the book also discusses aspects of morphology and syntax. A lot of previous research on the phonetics and phonology of HLs more generally has also concentrated on the pronunciation of specific segments in production and on their perception, on phonemic contrasts, VOT, and other segmental characteristics (see Montrul 2016:82-85 for a recent overview). Benmamoun et al. (2013:153) conclude that " $[p]$ honology in general seems to be the best-preserved area of heritage grammar." Recent studies on prosodic aspects have mainly focused on perceived global accent (Kupisch et al. 2014, Stangen et al. 2015, Bergmann et al. 2016), tone (for example, Chang \& Yao 2016), and the use of prosodic cues such as accent position in language processing (for example, Sekerina \& Trueswell 2011, Hoot 2012).

Previous research on intonation in the context of HLs has looked at intonational features in both the $\mathrm{HL}$ and the dominant language. Huffines (1986) studies the intonation of Pennsylvania German English (PGE), that is, the English of the descendants of German-speaking immigrants to Pennsylvania, and finds influence of PG on PGE. In her study comprising 50 speakers with varying proficiency, aged $\geq 41$ at the time, she finds two patterns in PGE intonation usually not found in the NAmEngl spoken in the area, one being $\mathrm{L} \%$ in $\mathrm{PQs}$, that is, an intonation contour falling to a low level at the end of the utterance. Of the $701 \mathrm{PQs}$ 
in her data set, $392(56 \%)$ were produced with final L\% as boundary tone of a rising-falling nuclear contour. The pattern was found throughout the PG community, that is, sociolinguistic factors such as age did not seem to play a role. Huffines (1986:31-32) also presents PQ examples of codeswitching. She finds that question intonation in $\mathrm{PG}$ is variable, exhibiting both PQs rising (to H\%) and PQs falling (to L\%). Huffines (1986:34) attributes the falling contours in PGE PQs to maintenance in PG, and then transfer of the maintained features into PGE. She argues that maintenance of intonational features and their transfer into the dominant language has a sociolinguistic function of expressing ethnic identity and belonging. Also, discussing interference patterns between NAmEngl and (Canadian) PG, Burridge (2007:194f.) argues that because intonation and stress are acquired early and before morphosyntactic features, it is unsurprising that they "are the ones we find most readily transferred from $\mathrm{PG}$ to $\mathrm{E}$ [nglish] ... [and] ... which in $\mathrm{PG}$ show the greatest resistance to influence from English." 4

Bullock's (2009) study of two speakers of moribund Frenchville French (Pennsylvania) reveals that some of the prosodic features of this heritage variety of French closely resemble features of its contact language, NAmEngl, but are strikingly different from the prosody of standard French as described in the literature. For example, in Frenchville French, focused elements, including pronouns, may be marked by in-situ prominence, as in English, while standard French uses syntax and prosodic phrasing. Moreover, the nuclear contour associated with left-dislocated elements is strikingly similar to that used in NAmEngl, but it lacks features of standard French. Bullock (2009:189) uses the term prosodic calquing to refer to this kind of borrowing of prosodic features, "a contact phenomenon [...] whereby a variety of intonation patterns from the dominant language are recruited into the minority language and employed for similar communication purposes."

Robles-Puente (2014) studies the intonation of Spanish in Los Angeles. He finds that in declaratives, Spanish heritage speakers retain pitch accent types and intonational contours specific to Spanish (for

\footnotetext{
${ }^{4}$ The PG speaking group that Burridge (2007) examines is comprised of "the Mennonite Anabaptists of Swiss-German origin, who left Pennsylvania for Canada after the American War of Independence. The majority settled in Waterloo County, where they remain today" (p. 179; see ibid. for details).
} 
example, prenuclear $\mathrm{L}^{*}+\mathrm{H}$, nuclear $\mathrm{L}+{ }_{i} \mathrm{H}^{*} \mathrm{~L} \%$ ) when speaking Spanish, and they also transfer them to their L2, English. ${ }^{5}$ At the same time, he finds that bilinguals also use accent types and contours specific to English (prenuclear $\mathrm{H}^{*}$, nuclear $\mathrm{H}^{*} \mathrm{~L} \%$ ) in their Spanish. Robles-Puente (2014) thus finds both maintenance of Spanish intonational features and mutual influence between the two languages, that is, transfer from L1 Spanish to L2 English as well as the other way around.

In Europe, Queen (2001) finds that, along with interference-based structures, Turkish/German bilingual children aged 10-12 also provide evidence of maintained language-specific intonation structures. For example, the Turkish question particle was produced with the typical Turkish intonation contour even when it was code-switched into a German utterance. Queen (2001) also finds the use of the Turkish utterance-final rise in both the German and Turkish interrogatives produced by the Turkish/German bilingual children. This specific contour- $\mathrm{L} \% \mathrm{H} \%$ in Queen 2001-typical for Turkish interrogative utterances, is never found in the speech of monolingual German children, but it occurs in the speech of their bilingual counterparts. At the same time, she finds the typical German rise, L* $\mathrm{H}-\mathrm{H} \%$, in both Turkish and German interrogatives. Taken together, these studies report maintenance of prosodic features in the HL, as well as bidirectional influence between the HL and the dominant language.

To study the intonation pattern of NAmIce speakers today, as well as potential interference or possible transfer from NAmEngl to NAmIce, it is important to know whether these speakers had fully acquired the intonation of their L1 Icelandic by the age of 5 or 6 , that is, by the age when NAmEngl became their dominant every-day language. I am not aware of a study on the L1 acquisition of Icelandic (IceIce or NAmIce) intonation until the critical age of 5. However, following recent research on the monolingual and bilingual L1 acquisition of intonation in other languages, it seems safe to assume that by the age of school entry, the NAmIce speakers had acquired the phonetics of interrogative intonation and the relationship of intonational contours to their meaning in context. For example, Lleó \& Rakow (2011) show that monolingual speakers of

\footnotetext{
${ }^{5}$ Note that in the Spanish ToBI $\left(\mathrm{Sp}_{-} \mathrm{ToBI}\right)$ conventions, the diacritic ; marks upstep, that is, the peak in $\mathrm{L}+{ }_{i} \mathrm{H}^{*}$ is upstepped (raised) as compared to a previous peak (see Beckman et al. 2002).
} 
both German and Spanish, as well as bilingual German/Spanish children, adequately produce target intonation contours in PQs no later than age $3 ; 0$. Prieto et al.'s (2011) study of one Spanish child shows that by the end of the time analyzed at age $2 ; 6$, the intonation contours of several utterance types, among them interrogatives, are produced correctly. Most interestingly in the present context, the phonetically correct and pragmatically adequate production of a PQ was documented at age 1;6.16 (Prieto et al. 2011:210; see also Prieto et al. 2012). Thorson et al. (2015) study PQ intonational patterns in monolingual Catalan- and Spanish-speaking children aged 1;5 (the age at which PQs are first uttered) to $2 ; 4$. They specifically investigate the relation between the intonational form of PQs and their pragmatic functions (informationseeking, confirmation-seeking, offers, pure and resumptive echoes). The authors compare the intonational-pragmatic pattern in PQs produced by the children with the one in PQs produced by adults in child-directed speech. The results show that in their production of PQs, the children make use of the same pitch patterns that were found in child-directed speech and which have been observed in the literature on Spanish and Catalan question intonation more generally. Regarding the relationship between form and meaning, the authors show that despite the intonational variation within pragmatic types expected in both child and adult language, "young children use a variety of interrogative intonation patterns in a pragmatically coherent way to signal communicative intent, confirming earlier accounts" (Thorson et al. 2015:95). Thus, at this early age children have already acquired form-meaning relationships in an adult-like way. I therefore assume that present-day NAmIce speakers had fully acquired the intonation of PQs by the time NAmEngl became their dominant language.

The aim of the current study is twofold. The first aim is to document the intonation of NAmIce PQs as a part of NAmIce intonation more generally, in comparison to NAmEngl as the dominant language and to modern IceIce as the best possible baseline. The second aim is to contribute to a better understanding of intonation in HLs more generally, including interference between the HL and the dominant language. The predictions of this study are formulated at the end of section 2 , based on the literature review in the current section as well as the syntactic and intonational properties of PQs in IceIce and NAmEngl introduced in section 2 . 
The remainder of the paper is organized as follows. Section 2 provides an introduction to the syntax and default intonation of PQs in IceIce and NAmEngl. Sections 3 through 5 report on the map task study carried out in Iceland and Manitoba, data treatment, and results. The results of the study are discussed in section 6 . Section 7 is a conclusion.

\section{The Syntax and Intonation of PQs in IceIce and NAmEngl.}

PQs in both IceIce and NAmEngl are verb first (V1) clauses. However, they differ in the verbal element occupying V1 position: In IceIce, both main and auxiliary verbs occur in V1 position; in NAmEngl, only auxiliaries occur in V1 position, but main verbs need do-support. The examples in 1 contain canonical PQs in IceIce and NAmEngl (the IceIce examples are from Thráinsson 2007:147).

(1) a. Hefur álfur-inn étið ost-inn?

IceIce

has elf-DEF.NOM eaten cheese.ACC-DEF.ACC

'Has the elf eaten the cheese?'

NAmEngl

b. Át álfur-inn ost-inn?

IceIce

ate elf-DEF.NOM cheese.ACC-DEF.ACC

'Did the elf eat the cheese?'

NAmEngl

The default intonation of IceIce PQs - as well as of declarative sentences and $w$-questions - is assumed to be falling to a low boundary tone (L\%; Árnason 1998, 2005, 2011, among others). According to Árnason (2005:477, 2011:323), PQs as well as wh-questions with rising intonation "have special connotations" (such as surprise or impatience) beyond being neutral and purely information seeking, while PQs with falling intonation are neutral. For example, $\mathrm{L}^{*}+\mathrm{H}$ combines with $\mathrm{L} \%$ in "matter of fact" $\mathrm{PQs}$ that function "as simple requests for information." In contrast, $\mathrm{H} \%$ may be used in a PQ that functions more like a "friendly suggestion [...], which calls for an immediate reply" (Árnason 1998:56). According to Árnason (2011:322-323), one intonational difference between IceIce statements and PQs is the type of nuclear accent. While the early rise $(\mathrm{L}+) \mathrm{H}^{*}$, that is, a rise to a high peak associated with the accented syllable, is the typical nuclear accent in statements (see also Dehé 2010), the late rise $\mathrm{L}^{*}+\mathrm{H}$, that is, a rise from a low accented syllable, is typical of PQs. The intonation contour of both neutral 
declaratives and neutral PQs continues with a fall after the peak, that is, both sentence types terminate in $\mathrm{L} \%$. According to the literature, the typical nuclear contour of IceIce PQs is thus a rise-fall (L*+H L-L\%). Example 2 shows an IceIce PQ with default intonation (from Árnason 2011:323).

(2) Er Nanna komin?

$$
\mathrm{L}^{*+\mathrm{H}} \quad \mathrm{L}-\mathrm{L} \%
$$

is Nanna arrived

'Has Nanna arrived (yet)?'

In contrast, the default intonational contour of PQs in NAmEngl is rising to a high final boundary tone $(\mathrm{H}-\mathrm{H} \%$; see Pierrehumbert \& Hirschberg 1990, Bartels 1999, Hedberg et al. 2017, among others). For example, Hedberg et al. (2017) find that $90.5 \%$ of PQs in their corpus study ( $\mathrm{N}=410$; verb-first PQs without negation) are rising, with the lowrise $\mathrm{L}^{*} \mathrm{H}-\mathrm{H} \%$ being the predominant nuclear contour $(\mathrm{N}=323$ out of 410). This is the same contour that has been referred to by Pierrehumbert \& Hirschberg $(1990: 290,292)$ as the "standard" or "canonical" contour for PQs, and by Bartels (1999:124) as the "most typical" in PQs.

This difference between IceIce and NAmEngl question intonation is also evident in the present data set (see section 5 below). These data confirm that rising intonation is typical of information-seeking PQs in NAmEngl, but falling intonation is typical of information-seeking PQs in IceIce. Representative examples of PQs from the present map task data are given in figure 1 for IceIce and figure 2 for NAmEngl. 


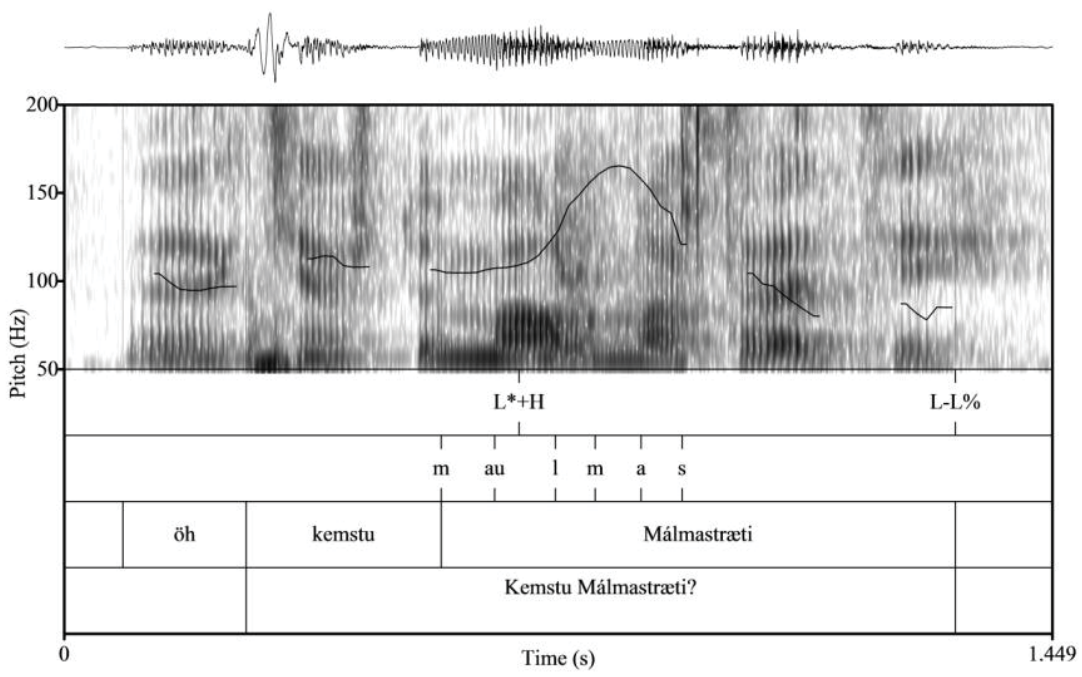

Figure 1. IceIce; nuclear contour L*+H L-L\%; speaker H14 (male).
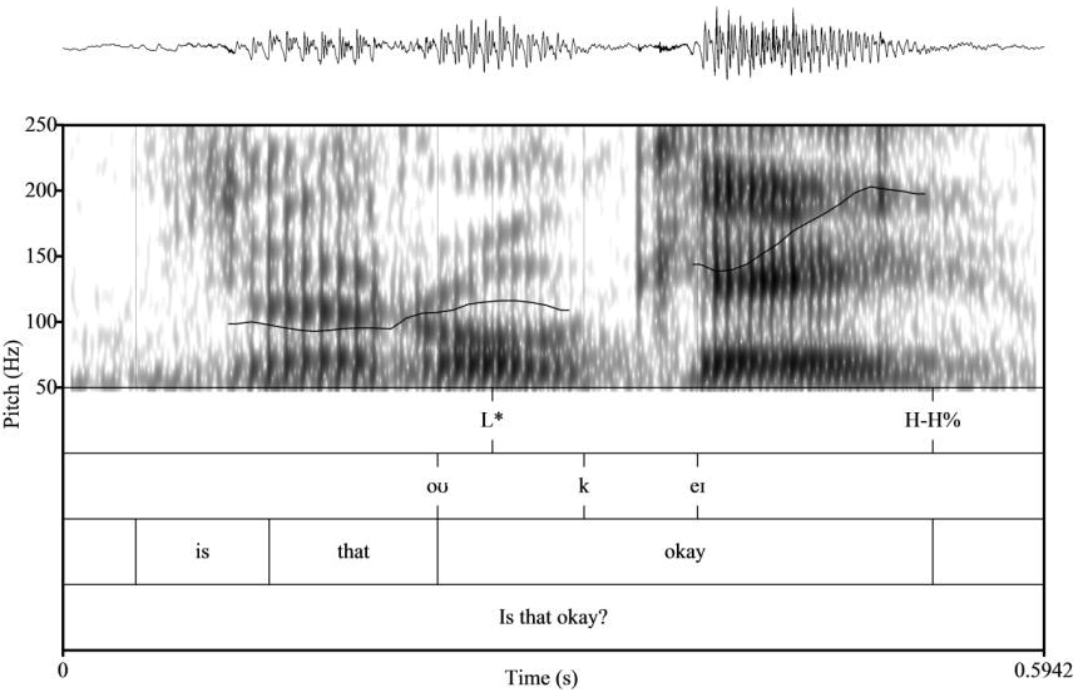

Figure 2. NAmEngl; nuclear contour L* H-H\%; speaker CW03 (male). 
In the IceIce PQ Kemstu Málmastrceti 'Can you take Málmastræti?' in figure 1, the nuclear syllable (the first syllable Mál /mâl/ of Málmastraeti) is associated with a low tonal target; the contour then rises to a local peak reached in the following syllable $m a / \mathrm{ma} /\left(\mathrm{L}^{*}+\mathrm{H}\right)$. Immediately after the peak, starting at the end of the second syllable, the contour falls toward the end of the question (L-L\%). Note that the third syllable of Málmastrceti, which bears secondary lexical stress, is associated with the fall and the low phrase accent L-. In the NAmEngl PQ in figure 2, the nuclear syllable (second syllable of okay) is associated with a low pitch accent $\mathrm{L}^{*}$, followed by a rise, such that the nuclear contour terminates in $\mathrm{H}-\mathrm{H} \%$.

In sum, the intonation in IceIce PQs is typically falling, with the risefall $\left(\mathrm{L}^{*}+\mathrm{H} \mathrm{L}-\mathrm{L} \%\right)$ being the default nuclear contour, while the intonation in NAmEngl PQs is typically rising, with the low-rise ( $\mathrm{L}^{*} \mathrm{H}-\mathrm{H} \%$ ) being the default nuclear contour. Thus, both languages have a clear default intonational pattern in PQs. Given the different intonational features of PQs in the two languages, NAmIce lends itself well to a study of HL intonation; in particular, NAmIce allows one to investigate interference between the HL (NAmIce) and the dominant language (NAmEngl). ${ }^{6}$ The obvious question is whether NAmIce shares the following characteristics with other HLs: i) whether intonational features such as the IceIce risefall are persistent, that is, whether they are maintained in NAmIce, ii) whether intonational features typical of NAmEngl, such as the nuclear low-rise, can be found in NAmIce, too, suggesting transfer from NAmEngl, and iii) whether transfer of intonational features is bidirectional such that Icelandic intonational features can also be found in the NAmEngl spoken by speakers with a NAmIce background. Based on the previous findings on the intonation of NAmEngl and IceIce PQs, combined with previous results on intonation in HL contexts (see section 1 above), the predictions of the present study are given below.

(i) Intonational features typical of IceIce PQ intonation can still be found in NAmIce. In particular, I predict considerable use of the

\footnotetext{
${ }^{6}$ Note that unlike the intonation of PQs, the intonation of $w h$-questions and declaratives is more similar in the two languages, and so interference effects would not be as clearly visible.
} 
low boundary tone $(\mathrm{L} \%)$ as well as the rise-fall nuclear contour in NAmIce PQs.

(ii) Tonal events typical of NAmEngl PQs are found in NAmIce PQs, too. In particular, I predict that compared with IceIce PQs, the high boundary tone $(\mathrm{H} \%)$ and the low-rise nuclear contour feature more prominently in NAmIce PQs.

(iii) Since interference between an HL and a dominant language has been shown to be bidirectional, I predict that compared with NAmEngl PQs produced by speakers without Icelandic background, the NAmEngl PQs produced by speakers with a NAmIce background contain more intonational features typical of Icelandic PQs (that is, L\%, nuclear rise-fall).

The results of the study reported below show that these predictions are borne out.

\section{Methodology.}

3.1. Data Source: The Icelandic Map Task.

The data used here are taken from a map task study carried out by the author of the present paper in Iceland during the months of October 2013 to January 2014 and May-June 2014, and in Manitoba, Canada in August 2014 (see also Dehé 2015). The map task has the advantage of eliciting quasi-spontaneous speech produced in an interactive discourse while at the same time allowing for i) some control over the lexical elements used by the participants and thus the segmental make-up of target elements, ii) comparability between groups of speakers, and iii) control over sociolinguistic factors such as age, regional origin, and the like. The same map task was carried out with speakers of IceIce in Iceland, and speakers of NAmEngl and NAmIce in Manitoba, Canada, allowing for comparison between the languages while keeping the task the same.

Versions of the map task have frequently been used in research on intonation (for example, Grice et al. 1995, Grice \& Savino 2003, Lickley et al. 2005, Savino 2012, Fletcher \& Stirling 2014). The maps used in the present study differ from maps used in previous map task experiments in two ways. First, unlike previous maps (for example, the maps pictured in Anderson et al. 1991, Grice \& Savino 2003, Helgason 2006, Savino 
2012, Fletcher \& Stirling 2014), none of the maps used in this study show routes. Second, instead of drawn objects, target words (street names and landmarks) were written on the maps, and crosses (X) marked intersections between streets and potential landmarks. In addition, as in Savino's (2012) study on Italian question intonation but not in other studies, the participants within each pair acted as both instruction givers and instruction followers to allow for maximal interaction. Four maps were created: two tourist (instruction follower) maps and two guide (instruction giver) maps; they are provided in figures 3 and 4 . The maps were designed as a grid, with street and landmark names. All the names were chosen based on their maximal sonority. I also made sure to select the same number of street and landmark names with open and closed first syllable. For example, streets: $\mathrm{N}=11$, as in Ninugata; landmarks: $\mathrm{N}=5$, as in Nínuverslun — open first syllable /ni:/; streets: $\mathrm{N}=11$, as in Lundahólar; landmarks: $\mathrm{N}=5$, as in Lundasafnið; closed first syllable /lyn/ (see 3 and 4). This was important because IceIce has word-initial primary stress (Einarsson 1973; Árnason 1985, 1987, 1998; Thráinsson 1994, among others). Control of syllable structure allows for the study of pitch-tosegment alignment (for example, Dehé 2010 for IceIce).

(3) Street names

a. Open first syllables: Mánagata, Melagata, Múlasíða, Mílugata, Melastrceti, Munagata, Nínugata, Mímisgata, Malarvegurinn, Lómastrceti, Málastrceti

b. Closed first syllables: Málmateigur, Mílnagata, Myndastrceti, Lindagata, Lambastroeti, Lundahólar, Moldargata, Mundagata, Mundastrceti, Mangavegur, Málmastrceti

(4) Landmark names

a. Open first syllables: Mánagarðurinn, Nínuverslun, Melabúðin, Málaskóli, Múlakaffi

b. Closed first syllables: Landakirkja, Lindakirkja, Myndasetrið, Myndastytta, Lundasafnið

The tourist maps (maps B and Bx; see upper panels in figures 3 and 4) have lists of landmarks at the bottom and Xs in every junction as 
potential sites of landmarks. The guide maps (maps An and Ax; see lower panels in figures 3 and 4) have all the landmarks in the junctions allowing for the guide to give directions to the tourist. For each experimental session, two participants, $\mathrm{P} 1$ and $\mathrm{P} 2$, were paired in such a way that they knew each other well (for example, close friends, life partners, parent and son or daughter) in order to allow for informal speech in a comfortable situation. In every session, each participant received one tourist map and one guide map. More specifically, participant P1 received tourist map Bx and guide map An (see the pair in figure 3), and participant P2 received tourist map B and guide map Ax (see the pair in figure 4). Hence, both participants played both roles, tourist and guide, in one experimental session.

The task of the tourist was to locate all landmarks given at the bottom of the map by asking the guide for directions. The task of the guide was to direct the tourist to these landmarks, using the street names provided on the map. The participants were instructed to avoid the words áfram 'forward, straight on', vinstri 'left', and hoegri 'right' to make sure they made use of the target street names as much as possible. Participants in Manitoba, who typically had little to no experience in reading IceIce, were given additional time to familiarize themselves with the names of streets and landmarks.

All four maps were slightly different in that the landmarks and the street names were identical, but the locations of some of them on the maps differed. The participants did not see each other's maps during the experimental session, and they were unaware of the fact that their maps were not the same. However, their task was to correctly locate their landmarks, anyway.

The participants usually switched roles each time they located a landmark shown on the map. For example, P1 (tourist) began by asking P2 (guide) for the location of her first landmark: Lundasafnid, so that she could locate it on her map Bx. P2 used his map Ax to guide P1 from her point of departure, Upphafsstaður, to this landmark. Since the maps were not identical, there had to be some interaction (such as questions and answers, imperatives, repair sequences) before P1 found the landmark. Once the landmark was located, the participants switched roles. P2, now the tourist, asked P1, now the guide, for directions to the landmark Landakirkja on his map B. P1 now used her map An to give directions until the landmark on P2's map B was located. The procedure was 
repeated until each participant found the last of the 10 landmarks listed on their tourist maps. To find the first landmark, the participants started at their point of departure. For every following landmark, they typically started from the one previously located.
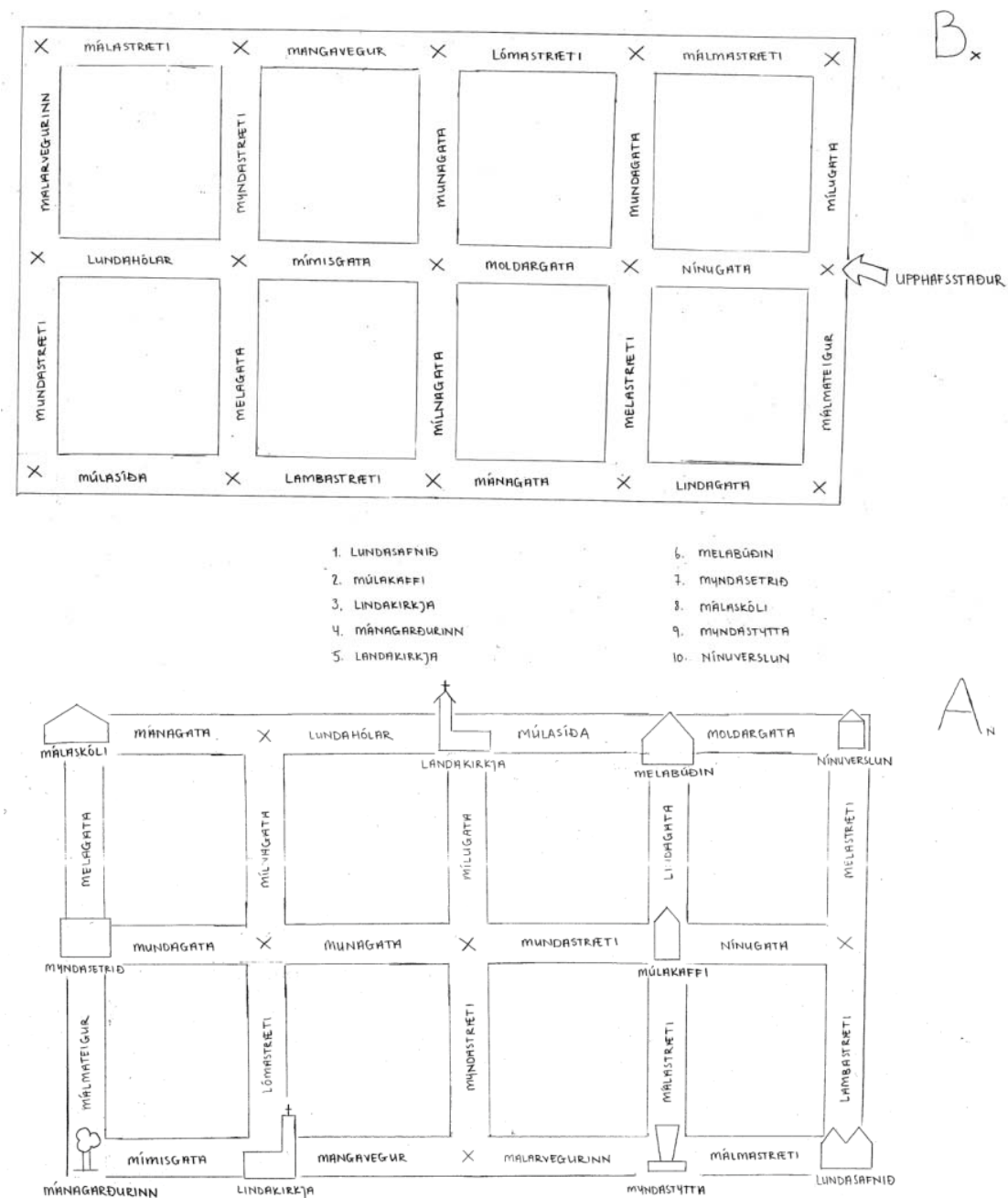

Figure 3. Maps used by P1; upper panel: tourist map Bx; lower panel: guide map An. 


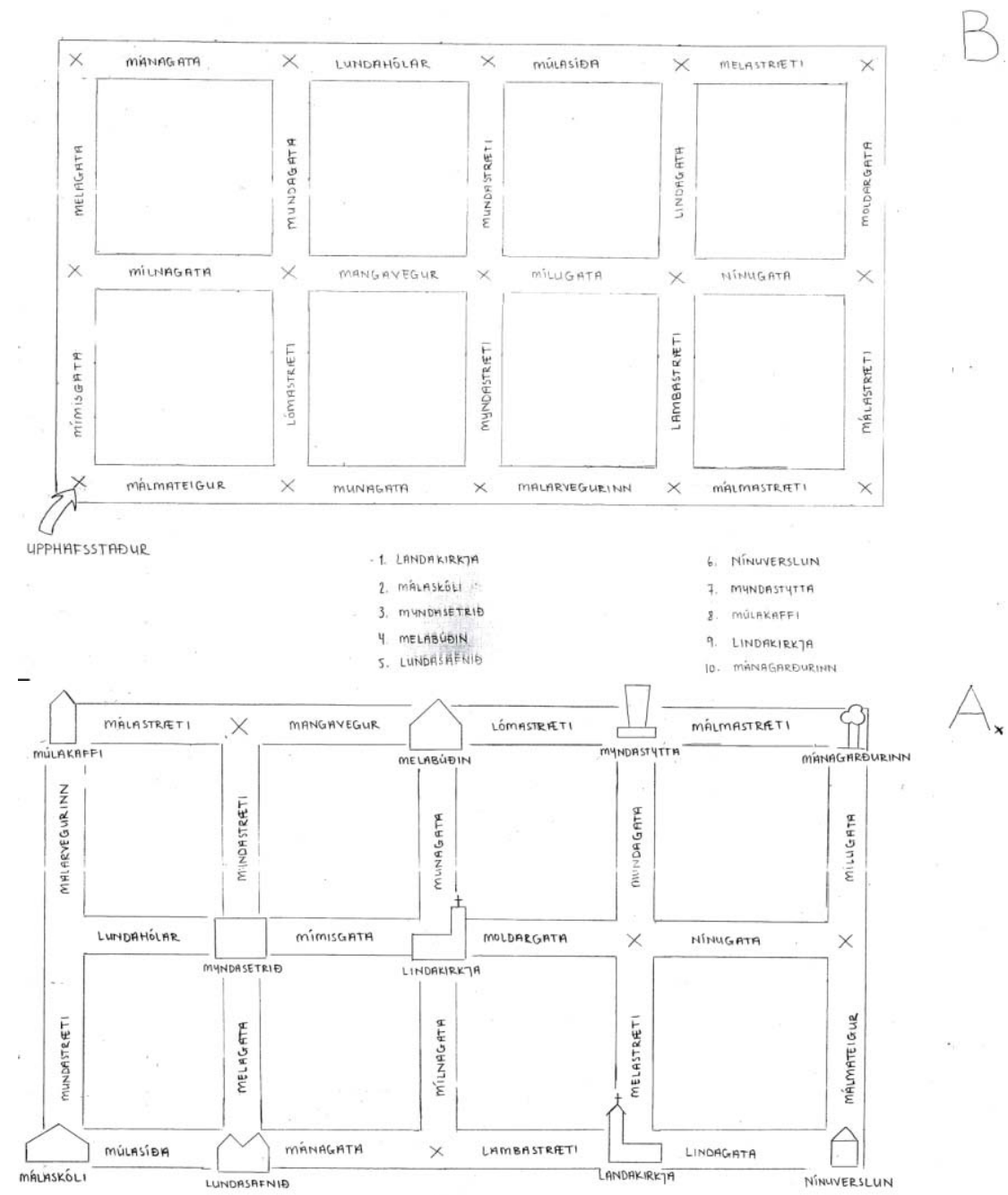

Figure 4. Maps used by P2; upper panel:

Tourist map B; lower panel: guide map Ax.

During each session, the participants were recorded using two Microtrack II (M-Audio) recorders and two Rode NT-5 condenser microphones. Two separate channels were used to avoid overlap when the participants were speaking simultaneously. Based on the recordings, all map task dialogues were transcribed orthographically by native 
speakers of IceIce. The dialogues were between 15 and 59 minutes in length (NAmIce dialogues between 23 and 50 minutes). Based on the transcripts, utterances were edited into individual sound files and saved and sorted according to syntactic utterance type (for example, PQ).

\subsection{Participants.}

Overall, 16 speakers of NAmIce ( 8 pairs) were recorded in three locations in Manitoba: Winnipeg (4 speakers; speaker identifier CW01, CW02, CW07, CW08), Gimli, on Lake Winnipeg (8 speakers; speaker identifier CG01-CG08), and Lundar, Interlake area (4 speakers; speaker identifier CL01-CL04). Speaker CL04 was later discarded from the analysis because she was of Swedish descent and had learned NAmIce only as an adult. Of the remaining 15 speakers (6 male, 9 female), 14 grew up in Manitoba. Of these, 13 were sequential bilinguals. Twelve of them grew up with L1 NAmIce until the age of 5 or 6 , that is, until school entry, when they started to speak NAmEngl, which then became their dominant language. One speaker (CW02) said she spoke NAmEngl before that age, that is, she was a simultaneous bilingual as she grew up with both languages as L1, but said that NAmIce was her first language. One speaker (CL01) said that NAmEngl was her first language, but NAmIce had been around from the very beginning, both in the family and outside home. Thus she, too, was a simultaneous bilingual. One participant (CW07) grew up in Iceland until age 11, and then moved to Canada, that is, she was a sequential bilingual growing up with L1 IceIce until age 11. All participants continued to speak NAmIce with family members during school breaks until at least the age of 16. Several speakers reported that they still speak some NAmIce, but only one speaker (CG04) said she did so regularly. One speaker (CW02) said she recently started language classes (10 evenings per year), while one other speaker (CL01) said she took regular language classes, but did not specify how frequently she took classes. The 15 NAmIce speakers were between 64 and 89 years of age at the time of recording (average 76.9 years). More information about the NAmIce speakers is provided in table A1 in the appendix to this paper.

Comparing the three locations (see table A1), it seems that the speakers tested in Gimli have one feature in common: They stated they still speak NAmIce, even if not on a regular basis. This is no surprise, given that Gimli is the center of Icelandic heritage and culture in Canada. 
The speakers recorded in the capital Winnipeg have stopped speaking NAmIce, or, in one case, have recently taken up (infrequent) language classes. In Lundar, the picture is mixed. Given these differences in frequency of NAmIce use, the results for the three locations are compared in the analysis (section 5.1).

Note that the NAmIce speakers were tested in NAmIce only, thus I do not have NAmEngl and NAmIce map task data sets from the same speakers. Crucially, this is due to the nature of the map task. It was essential that the participants not be aware at the beginning of the task that the maps used by each member of a pair were not the same. This condition would not have been met had the task been completed twice by the same speakers. Having instead some of the NAmIce speakers complete the task in NAmEngl and some in NAmIce would have reduced the number for NAmIce, because all available NAmIce speakers fluent enough to engage in map task-related conversations were tested. The map task was used to enable comparison with the IceIce data elicited in Iceland. Therefore, it was carried out in the same way in Iceland and Canada. ${ }^{7}$

Eighty-four speakers of IceIce (42 pairs) were recorded in three locations in Iceland: Reykjavík (24 speakers), Ísafjörður and Flateyri in the West Fjords (26 speakers), and Ólafsfjörður and Húsavík in the north (34 speakers). The data from two non-native speakers had to be discarded from the data set. For the current purpose, all speakers aged 64 and over were selected from the available data set to match the age of the group recorded in Manitoba and thus to control for healthy aging effects. The IceIce data reported here are thus taken from 12 speakers $(5$ male, 7 female) between 64 and 85 years of age at the time of recording (average 70.25). No speakers recorded in Reykjavík were included in this group in order to match the regional origin of the HL speakers as best as possible (see section 1 above). Instead, the speakers came from Húsavík (5 speakers; speaker identifiers H01, H02, H05, H13, H14), Ólafsfjörður (4 speakers; speaker identifiers Ó07, Ó08, Ó13, Ó14), and Ísafjörður (3 speakers; speaker identifiers Í02, Í03, Í17).

\footnotetext{
${ }^{7}$ Note that reading tasks would not have been an option, since NAmIce speakers have no training in reading and would not have been able to complete the task. Other spontaneous speech tasks would elicit even more variable data and thus would raise the question of comparability between the data sets.
} 
In addition to the data from these two groups (NAmIce speakers and IceIce speakers), four speakers of NAmEngl (2 male, 2 female), who had no knowledge of IceIce and were not of Icelandic descent, completed the map task in NAmEngl. They were between 60 and 79 years of age (average 71$)^{8}$

\section{Data Treatment.}

All information-seeking PQs produced by the three groups of participants were included in the analysis. All and only syntactically complete, verb-first, information-seeking $\mathrm{PQs}$ without negation were considered. Overall, 120 NAmIce PQs and 152 IceIce PQs were analyzed. In addition, 19 NAmEngl PQs produced by the NAmEngl speakers without Icelandic background were analyzed. Examples are given in 5-7.

(5) a. Do you meet up with Mílugata?

(NAmEngl: CW03-yn-Q11)

b. Then, when you get to a street called Myndastræti, can you turn left?

(NAmEngl: CW06-yn-Q07)

(6) a. Getur=ðu farið Moldargötu? (IceIce: H14-yn-Q09)

Can.2SG=2SG go-PART Moldargata.ACC

'Can you go (down) Moldargata?'

b. Ef pú ferð Mundagötu-na (IceIce: H14-yn-Q32)

If you.2SG go Mundagata.ACC-DEF.ACC

kemstu pá á Lómastræti?

can.you.take then onto Lómastræti

'If you go down Mundagata, can you then take Lómastræti?'

\footnotetext{
${ }^{8}$ A reviewer asks why only four NAmEngl speakers were recorded. This is because unlike the intonation of both IceIce and NAmIce, the intonation of NAmEngl is already very well documented in the literature. This includes the intonation of PQs (see section 2 and references given there, Hedberg et al. 2017, in particular). The intonational patterns produced by the four speakers confirm what is already known from the literature (see section 5.1).
} 
(7) a. Erum við búin með Lindakirkju? (NAmIce: CG05-yn-Q15) are.1SG we done with Lindakirkja.ACC

'Have we finished Landakirkja?'

b. Ætlar pú að byrja hjá upphafsstaður?

Intend you.2SG to begin at point.of.departure

'Are you going to start at the point of departure?'

(NAmIce: CG06-yn-Q27)

In addition, 28 NAmEngl PQs produced by NAmIce speakers as the result of code-switching were also analyzed (NAmEngl-csw). They were typically produced in one of the following three situations: First, during the map task, a participant had a question for the experimenter. Even though the experimenter spoke (non-native) IceIce in the experimental situation, some participants addressed the experimenter in NAmEngl. Second, at times there were pauses in the discourse, for example, when a participant did not immediately find a certain street or landmark and took time to locate it on the map. After such a pause, participants often restarted their conversation in NAmEngl, their dominant language, and had to be reminded to switch back to Icelandic. Third, the two participants in the same pair were unsuccessful in locating a landmark, and so they switched to NAmEngl to be able to communicate faster and more easily. They were then reminded to switch back to Icelandic.

All target utterances (that is, PQs and as much surrounding material as necessary) were prosodically analyzed in Praat (Boersma 2001, Boersma \& Weenink 2016). The PQs were analyzed using four tiers (see figure 1 repeated below as figure 5). Starting with the top one, they are: i) tonal tier for intonational analysis in terms of the nuclear contour, that is, nuclear pitch accent and edge tones; ii) tier showing phonetic transcription for segmental landmarks; iii) an orthographic tier containing word boundaries; iv) text tier containing the whole utterance. 


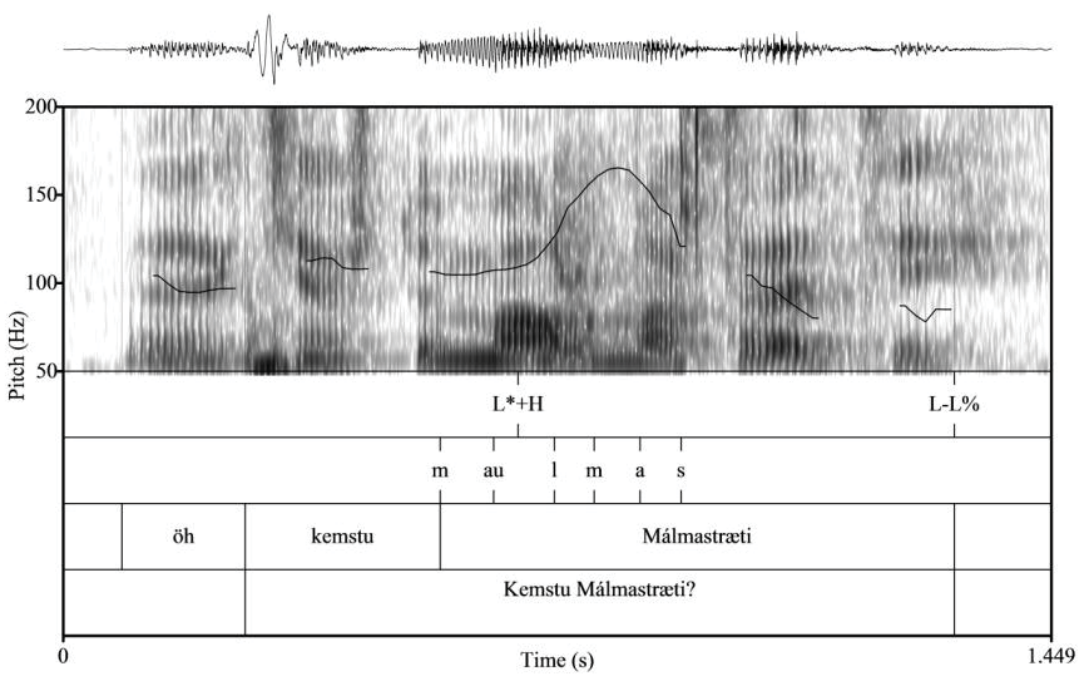

Figure 5. IceIce; nuclear contour L*+H L-L\%; speaker H14 (male).

The NAmEngl PQs were annotated on the tonal tier according to ToBI (Silverman et al. 1992, Beckman et al. 2005). The nuclear contours were holistically described following, among others, Hedberg et al. (2017), as in $\mathrm{L}^{*} \mathrm{H}-\mathrm{H} \%$ : low-rise; H* L-L\%: high-fall. The IceIce PQs were analyzed on the tonal tier, following previous intonational analyses of IceIce in the autosegmental-metrical framework (Dehé 2010). Nuclear rises were annotated $\mathrm{L}+\mathrm{H}^{*}$ when the peak $(\mathrm{H})$ was aligned within the nuclear syllable. This typically happened within the vowel in open syllables (CV:) and within the half-long consonant in closed syllables (CVC"; see Árnason 2011 for IceIce syllable structure). Nuclear rises were annotated $\mathrm{L}^{*}+\mathrm{H}$ when the high target was aligned in the syllable following the nuclear syllable. Nuclear contours of IceIce PQs were holistically described in the same way as the NAmEngl ones (for example, $\mathrm{L}^{*}+\mathrm{H} \mathrm{L}-\mathrm{L} \%$ : rise-fall). As far as the complete nuclear contours are concerned, $\mathrm{L}^{*}+\mathrm{H}$ and $\mathrm{L}+\mathrm{H}^{*}$ were grouped together as rises, and rises followed by a fall were described as rise-falls. Consequently, both $\mathrm{L}^{*}+\mathrm{H}$ $\mathrm{L}-\mathrm{L} \%$ and $\mathrm{L}+\mathrm{H}^{*} \mathrm{~L}-\mathrm{L} \%$ were described as rise-falls. The NAmIce PQs were analyzed accordingly.

All PQs analyzed in Praat were entered into an Excel file with their ToBI annotations and nuclear contour to allow for sorting according to relevant parameters and to perform basic analyses. The PQs were sorted 
by language (NAmEngl, IceIce, NAmIce), with the two English sets (NAmEngl, NAmEngl-csw) considered separately to begin with. Within languages, they were sorted according to intonational categories. Since rising (NAmEngl) versus falling (IceIce) nuclear PQ contours form a crucial contrast between the two languages, nuclear contours were divided into rises $(\mathrm{H} \%)$ and falls $(\mathrm{L} \%)$.

\section{Results.}

In this section, the results are first reported for NAmEngl, IceIce, and NAmIce separately and then compared. The focus is on the phonology of intonation rather than phonetic variation, that is, on the question of whether PQs are produced with rising $(\mathrm{H} \%)$ or falling (L\%) terminals, and on the default nuclear contours for PQs in the three groups.

\subsection{NAmEngl, IceIce, and NAmIce PQs.}

Let me begin with the NAmEngl group. First, the results for the NAmEngl PQs produced by the NAmEngl speakers without Icelandic background or knowledge of Icelandic are fully in line with previous assumptions about the intonation of NAmEngl PQs (see section 2 above) and with Hedberg, et al.'s (2017) corpus results. Of the 19 questions, 15 (79\%) were produced with a low-rise ( $\mathrm{L}^{*} \mathrm{H}-\mathrm{H} \%$ or $\mathrm{L} * \mathrm{~L}-\mathrm{H} \%$; see figure 2 in section 2 above for an example). Of the remaining four questions, two (10.5\%) were produced with a rise-fall-rise $\left(\mathrm{L}+\mathrm{H}^{*} \mathrm{~L}-\mathrm{H} \%\right)$ and two with a high-fall $\left(\mathrm{H}^{*} \mathrm{~L}-\mathrm{L} \%\right)$. Overall, 17 PQs $(89.5 \%)$ were thus produced with a rising contour, and only 2 PQs $(10.5 \%)$ with a falling contour. This distribution is in line with all the previous literature on the intonation of NAmEngl PQs.

Second, the results for the NAmEngl PQs produced by NAmIce speakers while code-switching (NAmEngl-csw) show a slightly lower percentage of rising contours. Of the 28 questions, 19 (67.9\%) were produced with a low-rise. In addition, three $(10.7 \%)$ were produced with a fall-rise ( $\left.\mathrm{L}+\mathrm{H}^{*} \mathrm{~L}-\mathrm{H} \%\right)$, so that overall, $22 \mathrm{PQs}(78.6 \%)$ were realized with a rising terminal. The remaining six $\mathrm{PQs}$ were produced with a falling contour; more specifically, with either a high-fall ( $\mathrm{H}^{*} \mathrm{~L}-\mathrm{L} \%$; $\left.\mathrm{N}=3,10.7 \%\right)$ or a rise-fall $\left(\mathrm{L}^{*}+\mathrm{H} \mathrm{H}-\mathrm{L} \% ; \mathrm{N}=3,10.7 \%\right)$. The distribution of intonational patterns for the two groups is provided in table 1 . 


\begin{tabular}{|c|c|c|c|c|}
\hline Group & $\begin{array}{l}\text { Nuclear } \\
\text { contour }\end{array}$ & Total N & Percentage & $\begin{array}{c}\text { ToBI } \\
\text { category }\end{array}$ \\
\hline \multirow[t]{7}{*}{ NAmEngl } & \multirow{2}{*}{ low-rise } & 10 & $52.6 \%$ & $\mathrm{~L} * \mathrm{H}-\mathrm{H} \%$ \\
\hline & & 5 & $26.3 \%$ & L* L-H\% \\
\hline & rise-fall-rise & 2 & $10.5 \%$ & $\mathrm{~L}+\mathrm{H}^{*} \mathrm{~L}-\mathrm{H} \%$ \\
\hline & overall rise & 17 & $89.5 \%$ & \\
\hline & high-fall & 2 & $10.5 \%$ & $\mathrm{H}^{*} \mathrm{~L}-\mathrm{L} \%$ \\
\hline & overall fall & 2 & $10.5 \%$ & \\
\hline & overall & 19 & $100 \%$ & \\
\hline \multirow[t]{8}{*}{ NAmEngl-csw } & \multirow{2}{*}{ low-rise } & 17 & $60.7 \%$ & $\mathrm{~L} * \mathrm{H}-\mathrm{H} \%$ \\
\hline & & 2 & $7.2 \%$ & L* L-H\% \\
\hline & (rise-)fall-rise & 3 & $10.7 \%$ & $(\mathrm{~L}+) \mathrm{H}^{*} \mathrm{~L}-\mathrm{H} \%$ \\
\hline & overall rise & 22 & $78.6 \%$ & \\
\hline & high-fall & 3 & $10.7 \%$ & (!)H* L-L\% \\
\hline & rise-fall & 3 & $10.7 \%$ & $\begin{array}{l}\mathrm{L} *+\mathrm{H} \mathrm{H}-\mathrm{L} \% \\
\mathrm{~L}+\mathrm{H}^{*} \mathrm{~L}-\mathrm{L} \%\end{array}$ \\
\hline & overall fall & 6 & $21.4 \%$ & \\
\hline & overall & 28 & $100 \%$ & \\
\hline
\end{tabular}

Table 1. Distribution of nuclear contours in NAmEngl PQs.

To test the significance of the difference between NAmEngl and NAmEngl-csw (89.5\% versus $78.6 \%$ rising contours), a linear mixedeffects logistic regression model was calculated using the lme4-library in R (Version 3.1.0; Bates \& Sarkar 2007). The dependent variable was binary coded (occurrence of overall rise: yes/no), Group was entered as a fixed factor and Speaker as a random effects factor, allowing for random intercept and slope (see Jaeger 2008). The results for the variable Rise versus Fall turned out not to be significant ( $\mathrm{p}>0.3$ ). Therefore, the two NAmEngl groups have been combined in the subsequent comparisons (see table 2): $83 \%$ rising $\mathrm{PQs}(\mathrm{N}=39)$ and $17 \%$ falling $\mathrm{PQs}(\mathrm{N}=8)$. I return to this issue in section 6 below. For the high fall in table 2, (!) indicates that both $\mathrm{H}^{*}$ and downstepped $! \mathrm{H}^{*}$ are included. 


\begin{tabular}{|c|c|c|c|c|}
\hline Group & $\begin{array}{l}\text { Nuclear } \\
\text { contour }\end{array}$ & Total N & Percentage & $\begin{array}{c}\text { ToBI } \\
\text { category }\end{array}$ \\
\hline \multirow{8}{*}{$\begin{array}{l}\text { NAmEngl; } \\
\text { two groups } \\
\text { combined }\end{array}$} & \multirow{2}{*}{ low-rise } & 27 & $57.5 \%$ & $\mathrm{~L}^{*} \mathrm{H}-\mathrm{H} \%$ \\
\hline & & 7 & $14.9 \%$ & L* L-H\% \\
\hline & (rise-)fall-rise & 5 & $10.6 \%$ & $(\mathrm{~L}+) \mathrm{H}^{*} \mathrm{~L}-\mathrm{H} \%$ \\
\hline & overall rise & 39 & $83 \%$ & \\
\hline & high-fall & 5 & $10.6 \%$ & (!)H* L-L\% \\
\hline & rise-fall & 3 & $6.4 \%$ & $\begin{array}{l}\mathrm{L}^{*}+\mathrm{H} \text { H-L\% } \\
\mathrm{L}+\mathrm{H}^{*} \mathrm{~L}-\mathrm{L} \%\end{array}$ \\
\hline & overall fall & 8 & $17 \%$ & \\
\hline & overall & 47 & $100 \%$ & \\
\hline
\end{tabular}

Table 2. Distribution of nuclear contours in PQs:

Combined results for NAmEngl and NAmEngl-csw.

Now consider the IceIce group. The results for IceIce show that IceIce PQs are predominantly falling, as previously noted in the literature (Árnason 1998, 2005, 2011, among others). Specifically, of the 152 IceIce PQs analyzed here, $132(86.8 \%)$ were falling, while only 20 $(13.2 \%)$ were rising. Within the falls, nuclear rise-falls $(\mathrm{N}=99)$ were more frequent than nuclear high-falls $(\mathrm{N}=33)$. The contours observed with IceIce PQs are presented in table 3, showing that the rise-fall is the most frequent nuclear contour (see figure 5 for an example), followed by the high-fall. 


\begin{tabular}{|c|c|c|c|c|}
\hline Group & $\begin{array}{l}\text { Nuclear } \\
\text { contour }\end{array}$ & Total N & Percentage & $\begin{array}{c}\text { ToBI } \\
\text { category }\end{array}$ \\
\hline \multirow[t]{11}{*}{ IceIce } & \multirow[t]{2}{*}{ low-rise } & 8 & $5.3 \%$ & L* H-H\% \\
\hline & & 8 & $5.3 \%$ & $\mathrm{~L} *+\mathrm{H} \mathrm{H}-\mathrm{H} \%$ \\
\hline & \multirow{2}{*}{ rise-fall-rise } & 1 & $0.6 \%$ & L*+H L-H\% \\
\hline & & 3 & $2 \%$ & $\mathrm{~L}+\mathrm{H}^{*} \mathrm{~L}-\mathrm{H} \%$ \\
\hline & overall rise & 20 & $13.2 \%$ & \\
\hline & \multirow{3}{*}{ rise-fall } & 1 & $0.6 \%$ & L*+H H-L $\%$ \\
\hline & & 13 & $8.6 \%$ & L*+H L-L\% \\
\hline & & 85 & $55.9 \%$ & $\mathrm{~L}+\mathrm{H}^{*} \mathrm{~L}-\mathrm{L} \%$ \\
\hline & high-fall & 33 & $21.7 \%$ & (!)H* L-L\% \\
\hline & overall fall & 132 & $86.8 \%$ & \\
\hline & Overall & 152 & $100 \%$ & \\
\hline
\end{tabular}

Table 3. Distribution of nuclear contours in IceIce PQs.

Finally, I discuss the results for the NAmIce group. While NAmEngl PQs are typically rising and IceIce PQs are typically falling, the results regarding rises versus falls are more balanced for NAmIce PQs. Table 4 provides all observed nuclear contours. Overall, 72 NAmIce PQs (60\%) had a rising terminal. The remaining 48 PQs $(40 \%)$ were produced with a falling contour. Within the rises, the low-rise was the most frequent nuclear contour $(\mathrm{N}=68 ; 56.7 \%)$. Other rising patterns were the fall-rise $(\mathrm{N}=3 ; 2.5 \%)$ and the rise-fall-rise $(\mathrm{N}=1 ; 0.8 \%)$. Falls were either a risefall $(\mathrm{N}=39 ; 32.5 \%)$ or a high-fall $(\mathrm{N}=9 ; 7.5 \%)$. The two most frequent contours, low-rise and rise-fall, are illustrated in figures 6 and 7, respectively, using representative NAmIce PQs from speaker CG03 (female). 


\begin{tabular}{|c|c|c|c|c|}
\hline Group & $\begin{array}{l}\text { Nuclear } \\
\text { contour }\end{array}$ & Total N & Percentage & $\begin{array}{c}\text { ToBI } \\
\text { category }\end{array}$ \\
\hline \multirow[t]{14}{*}{ NAmIce } & \multirow[t]{4}{*}{ low-rise } & 55 & $45.8 \%$ & $\mathrm{~L} * \mathrm{H}-\mathrm{H} \%$ \\
\hline & & 6 & $5 \%$ & L* L-H\% \\
\hline & & 6 & $5 \%$ & $\mathrm{~L}^{*}+\mathrm{H} \mathrm{H}-\mathrm{H} \%$ \\
\hline & & 1 & $0.8 \%$ & $\mathrm{~L}+\mathrm{H}^{*} \mathrm{H}-\mathrm{H} \%$ \\
\hline & \multirow[t]{2}{*}{ (rise-)fall-rise } & 3 & $2.5 \%$ & $(\mathrm{~L}+) \mathrm{H}^{*} \mathrm{~L}-\mathrm{H} \%$ \\
\hline & & 1 & $0.8 \%$ & L*+H L-H $\%$ \\
\hline & overall rise & 72 & $60 \%$ & \\
\hline & \multirow{4}{*}{ rise-fall } & 8 & $6.7 \%$ & L*+H H-L\% \\
\hline & & 13 & $10.8 \%$ & L*+H L-L\% \\
\hline & & 5 & $4.2 \%$ & $\mathrm{~L}+\mathrm{H}^{*} \mathrm{H}-\mathrm{L} \%$ \\
\hline & & 13 & $10.8 \%$ & $\mathrm{~L}+\mathrm{H}^{*} \mathrm{~L}-\mathrm{L} \%$ \\
\hline & high-fall & 9 & $7.5 \%$ & $(!) H^{*} \mathrm{~L}-\mathrm{L} \%$ \\
\hline & overall fall & 48 & $40 \%$ & \\
\hline & overall & 120 & $100 \%$ & \\
\hline
\end{tabular}

Table 4. Distribution of nuclear contours in NAmIce PQs.

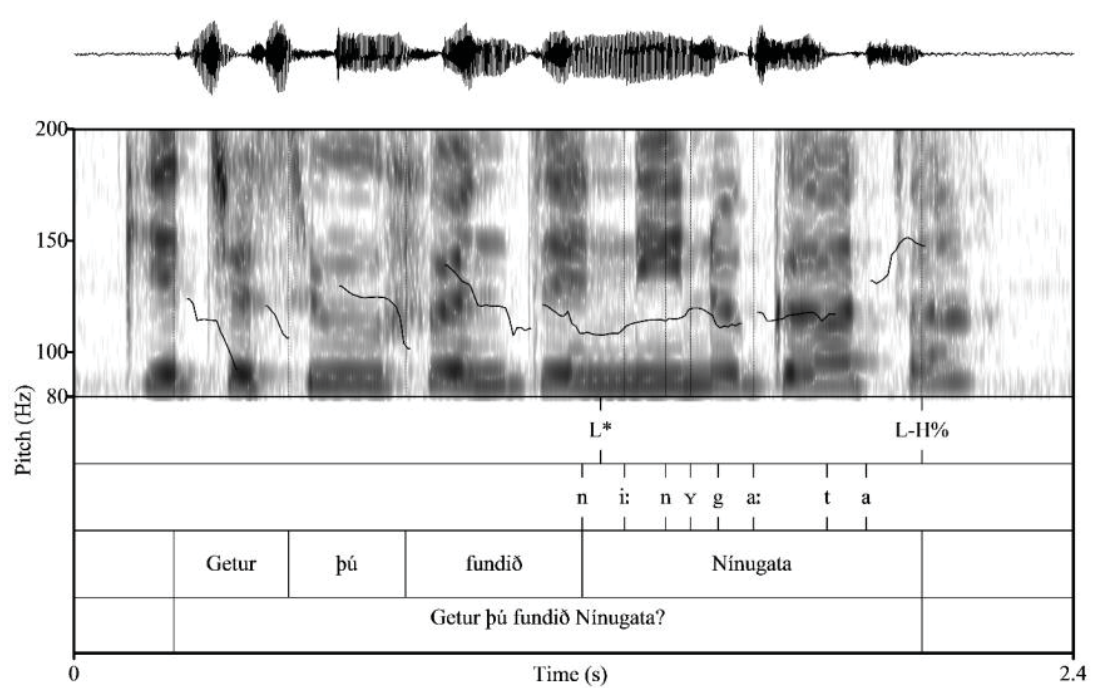

Figure 6. Getur pú fundið Nínugata 'Can you find Nínugata?' Nuclear contour: low-rise (L* L-H\%). 


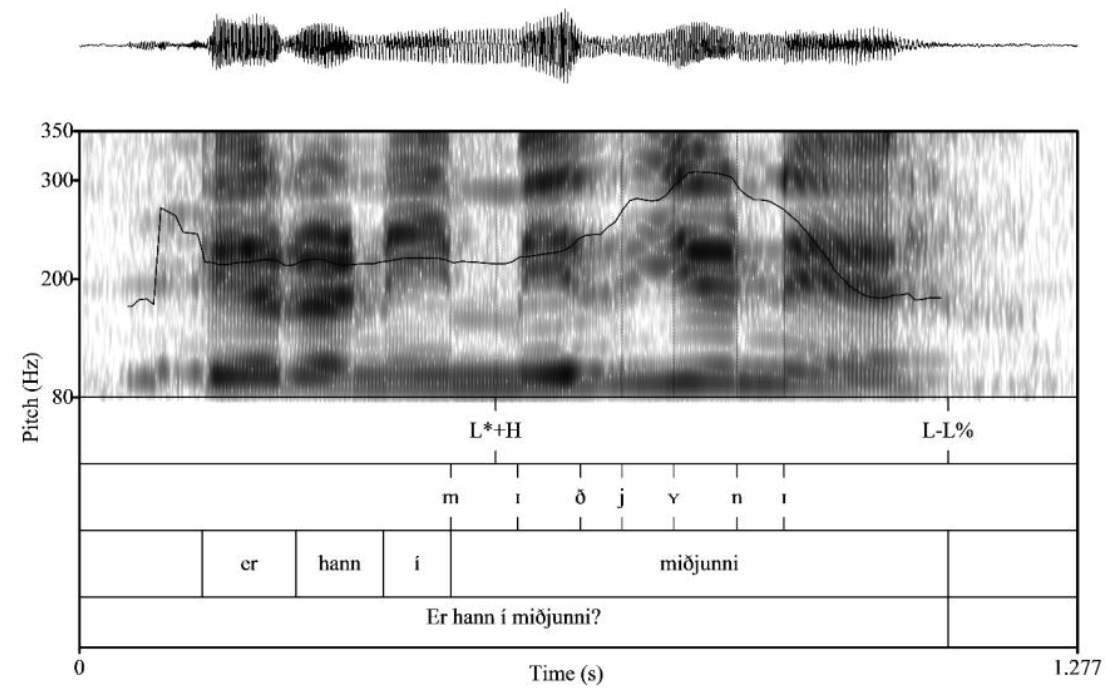

Figure 7. Er hann i miðjunni 'Is he [it] in the middle?' Nuclear contour: rise-fall ( $\left.\mathrm{L}^{*}+\mathrm{H} \mathrm{L}-\mathrm{L} \%\right)$.

Given the general distribution of intonational contours within the NAmIce group and the differences in language use between the three locations (Winnipeg, Gimli, Lundar; see section 3.2), it makes sense to compare the distribution of rises and falls between the three locations (see table 5 and figure 8). I calculated a generalized linear mixed effects model with Rise (yes/no) as a dependent variable and Location as a fixed factor. As before, Speaker was entered as a random effects factor (random intercept and slope). A binomial linking function was applied in order to account for the binary character of the dependent variable (Rise). While overall more falls were produced in Gimli than in both Lundar and Winnipeg, differences between the three locations in the fall:rise ratios turned out not to be significant (all comparisons $\mathrm{p}>0.1$ ).

\begin{tabular}{|l|r|r|c|c|}
\hline Location & rise N (\%) & \multicolumn{1}{|c|}{ fall N (\%) } & N total & ratio fall:rise \\
\hline Gimli (CG) & $50(58.8 \%)$ & $35(41.2 \%)$ & 85 & 0.7 \\
\hline Lundar (CL) & $15(62.5 \%)$ & $9(37.5 \%)$ & 24 & 0.6 \\
\hline Winnipeg (CW) & $7(63.6 \%)$ & $4(36.4 \%)$ & 11 & 0.57 \\
\hline total & 72 & 48 & 120 & 0.67 \\
\hline
\end{tabular}

Table 5. Distribution of rises and falls as a function of region. 


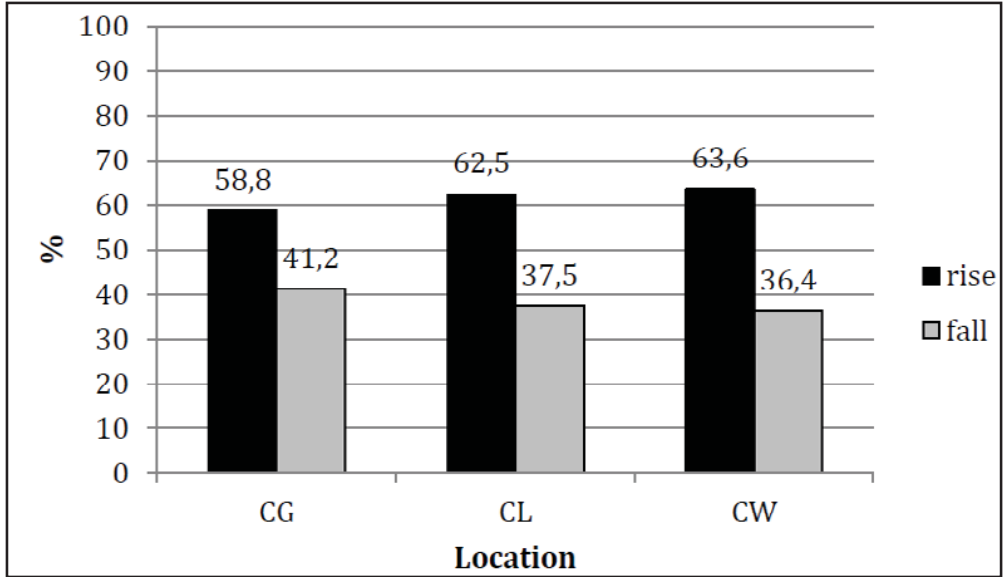

Figure 8. Distribution of rises and falls as a function of region.

Next, the results for individual speakers appear in table 6 and figure 9 . 


\begin{tabular}{|l|l|r|r|r|c|}
\hline Location & Speaker & rise (N) & fall (N) & total (N) & ratio fall:rise \\
\hline Gimli (CG) & CG01 & 7 & 2 & 9 & 0.3 \\
\cline { 2 - 7 } & CG02 & 0 & 2 & 2 & \\
\cline { 2 - 6 } & CG03 & 4 & 10 & 14 & 2.5 \\
\cline { 2 - 6 } & CG04 & 0 & 3 & 3 & \\
\cline { 2 - 6 } & CG05 & 5 & 5 & 10 & 1 \\
\cline { 2 - 6 } & CG06 & 22 & 3 & 25 & 0.1 \\
\cline { 2 - 6 } & CG07 & 3 & 5 & 8 & 1.7 \\
\cline { 2 - 6 } & CG08 & 9 & 5 & 14 & 0.6 \\
\hline \multirow{5}{*}{ Lundar (CL) } & CL01 & 3 & 3 & 6 & 1 \\
\cline { 2 - 6 } & CL02 & 2 & 1 & 3 & 0.5 \\
\cline { 2 - 6 } & CL03 & 10 & 5 & 15 & 0.5 \\
\hline \multirow{5}{*}{ Winnipeg (CW) } & CW01 & 3 & 2 & 5 & 0.2 \\
\cline { 2 - 6 } & CW02 & 2 & 0 & 2 & \\
\cline { 2 - 6 } & CW07 & 1 & 2 & 3 & 2 \\
\cline { 2 - 6 } & CW08 & 1 & 0 & 1 & \\
\hline \multirow{5}{*}{ total } & & 72 & 48 & 120 & 0.6 \\
\hline
\end{tabular}

Table 6. Distribution of rises and falls by speaker.

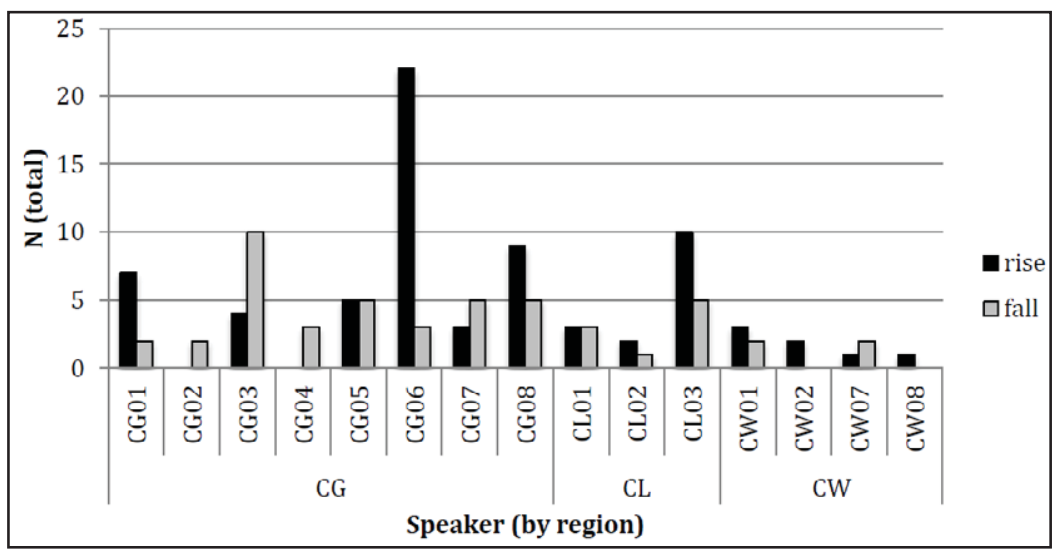

Figure 9. Distribution of rises and falls by speaker. 
The data in table 6 and figure 9 show that except for four speakers (CG02, CG04, CW02, and CW08), all speakers produce both rises and falls. Speakers CG02 and CG04 (both from Gimli) produce only falls, while speakers CW02 and CW01 (from Winnipeg) produce only rises. However, total item numbers are very low for all four speakers $(\mathrm{N} \leq 3)$, thus no further conclusions can be drawn from these numbers. All other speakers produced both rises and falls. ${ }^{9}$

\subsection{Comparisons Between Groups.}

For a comparison between the groups (NAmEngl, IceIce, and NAmIce), a linear mixed-effects logistic regression model was run with Group as a fixed factor and Speaker as a random effects factor. First, I compared the distribution of falling versus rising contours in the three groups (the dependent variable for statistical analysis: L\% versus $\mathrm{H} \%$ ). Distribution numbers and ratios are given in table 7 , which shows that rises $(\mathrm{H} \%)$ are more frequent than falls (L\%) in both NAmEngl and NAmIce PQs, while falls are more frequent than rises in IceIce. The results are highly significant: i) NAmEngl PQs have significantly more rises than IceIce PQs ( $83 \%$ versus $13 \%$; $\beta=4.44, \mathrm{SE}=0.69, \mathrm{z}=6.4, \mathrm{p}<0.0001$ ); ii) NAmIce PQs also have significantly more rises than IceIce $P Q s$, although the difference is smaller $(60 \%$ versus $13 \% ; \beta=2.74, \mathrm{SE}=0.53, \mathrm{z}=5.1, \mathrm{p}<0.0001)$; iii) crucially, NAmIce PQs also have significantly fewer rises than NAmEngl PQs $(60 \%$ versus $83 \%$; $\beta=1.70, S E=0.54, z=3.16, p<0.002)$.

\footnotetext{
${ }^{9}$ Note that Speaker was included as a random effects factor in the statistical analysis (see above). It would be interesting to include other speaker variables in the statistical analysis, but since most of them are highly correlated with location, this is not possible. Moreover, there are too few data points for some speakers. Note also that a larger group of participants would naturally have been helpful. However, given that NAmIce is a moribund language, with few speakers fluent enough to allow for intonational analysis, 15 speakers is in fact a very good group size.
} 


\begin{tabular}{|l|c|c|c|c|}
\hline Group & total (N) & $\mathbf{L \%}(\mathbf{N})$ & $\mathbf{H \%}$ (N) & ratio L\% : H\% \\
\hline NAmEngl & 47 & 8 & 39 & 0.2 \\
\hline IceIce & 152 & 132 & 20 & 6.6 \\
\hline NAmIce & 120 & 48 & 72 & 0.7 \\
\hline
\end{tabular}

Table 7. Distribution numbers and ratios for falling (L\%) versus rising $(\mathrm{H} \%)$ PQ contours.

Second, I compared the distribution of two most frequent nuclear contours: the low-rise and the rise-fall (the dependent variable: presence versus absence of low-rise). The low-rise is the default nuclear contour in NAmEngl and NAmIce PQs, but it occurs less frequently in NAmIce. The distribution numbers (for the low-rise as compared to all other contours) and ratios are given in table 8 . The results are as follows: i) NAmEngl PQs have significantly more low-rises than IceIce PQs $(72 \%$ versus $11 \%, \beta=4.00, \mathrm{SE}=0.68, \mathrm{z}=5.88, \mathrm{p}<0.0001$ ); ii) NAmIce PQs also have significantly more low-rises than IceIce PQs $(57 \%$ versus $11 \%$, $\beta=2.76, \mathrm{SE}=0.55, \mathrm{z}=4.97, \mathrm{p}<0.0001$ ); finally, iii) NAmEngl PQs have significantly more low-rises than NAmIce PQs ( $72 \%$ versus $57 \%$, $\beta=1.24, \mathrm{SE}=0.50, \mathrm{z}=2.47, \mathrm{p}=0.01)$.

\begin{tabular}{|l|c|c|c|c|}
\hline Group & $\begin{array}{c}\text { total } \\
(\mathbf{N})\end{array}$ & $\begin{array}{c}\text { low-rise } \\
(\mathbf{N})\end{array}$ & $\begin{array}{c}\text { no low-rise } \\
(\mathbf{N})\end{array}$ & $\begin{array}{c}\text { ratio low-rise : } \\
\text { no low-rise }\end{array}$ \\
\hline NAmEngl & 47 & 34 & 13 & 2.6 \\
\hline IceIce & 152 & 16 & 136 & 0.1 \\
\hline NAmIce & 120 & 68 & 52 & 1.3 \\
\hline
\end{tabular}

Table 8. Distribution numbers and ratios for the low-rise (L* H-H\%, L* L-H\%).

While the low-rise is the default contour in NAmEngl PQs, the risefall is the default nuclear contour in IceIce PQs. A comparison was therefore also calculated for the rise-fall (the dependent variable: presence versus absence of rise-fall). The distribution numbers (for the rise-fall as compared to all other contours) and ratios are given in table 9. The results show that i) NAmEngl PQs have significantly fewer rise-falls than IceIce PQs $(6 \%$ versus $65 \%, \beta=4.03, \mathrm{SE}=0.82, \mathrm{z}=4.92, \mathrm{p}<000001)$; ii) NAmIce PQs have significantly fewer rise-falls than IceIce PQs $(33 \%$ 
versus $65 \%, \beta=1.48, \mathrm{SE}=0.51, \mathrm{z}=2.93, \mathrm{p}<0.005$ ); iii) NAmEngl PQs have significantly fewer rise-falls than NAmIce PQs $(6 \%$ versus $33 \%, \beta=2.55$, $\mathrm{SE}=0.74, \mathrm{z}=3.41, \mathrm{p}<0.001$ ).

\begin{tabular}{|l|c|c|c|c|}
\hline Group & $\begin{array}{c}\text { total } \\
(\mathbf{N})\end{array}$ & $\begin{array}{c}\text { rise-fall } \\
(\mathbf{N})\end{array}$ & $\begin{array}{c}\text { no rise-fall } \\
(\mathbf{N})\end{array}$ & $\begin{array}{c}\text { ratio rise-fall : } \\
\text { no rise-fall }\end{array}$ \\
\hline NAmEngl & 47 & 3 & 44 & 0.1 \\
\hline IceIce & 152 & 99 & 53 & 1.9 \\
\hline NAmIce & 120 & 39 & 81 & 0.5 \\
\hline
\end{tabular}

Table 9. Distribution numbers and ratios for the rise-fall.

The final comparison focuses on the nuclear rise-fall in the two Icelandic varieties, IceIce and NAmIce (the dependent variable: $\mathrm{L}+\mathrm{H}^{*}$ versus $\left.\mathrm{L}^{*}+\mathrm{H}\right)$. The distribution numbers and ratios are given in table 10 .

\begin{tabular}{|l|c|c|c|c|}
\hline Group & total $(\mathbf{N})$ & $\mathbf{L}+\mathbf{H}^{*}(\mathbf{N})$ & $\mathbf{L}^{*+\mathbf{H}}(\mathbf{N})$ & ratio $\mathbf{H}^{*}: \mathbf{L}^{*}$ \\
\hline IceIce & 99 & 85 & 14 & 6.1 \\
\hline NAmIce & 39 & 18 & 21 & 0.9 \\
\hline
\end{tabular}

Table 10. Distribution numbers and ratios for $\mathrm{L}+\mathrm{H}^{*}$ and $\mathrm{L}^{*}+\mathrm{H}$ in rise-fall nuclear contours in IceIce and NAmIce PQs.

Variation in the realization of the rise can be observed. Nuclear rises in IceIce PQs typically have early peaks, that is, the rise is completed within the nuclear syllable $\left(\mathrm{L}+\mathrm{H}^{*}\right)$. By contrast, the distribution is almost balanced in NAmIce PQs, with slightly more late peaks $\left(\mathrm{L}^{*}+\mathrm{H}\right)$ than early peaks $\left(\mathrm{L}+\mathrm{H}^{*}\right)$. This difference is statistically significant such that NAmIce $\mathrm{PQs}$ have significantly fewer early peaks $\left(\mathrm{L}+\mathrm{H}^{*}\right)$ than IceIce PQs $(\beta=2.08, S E=0.54, z=3.86, p=0.0001)$.

\section{Discussion.}

In this section, the results reported in section 5 are discussed, focusing first and foremost, but not exclusively, on the predictions put forward at the end of section 2 and repeated below for convenience: 
(i) Intonational features typical of IceIce PQ intonation can still be found in NAmIce. In particular, I predict considerable use of the low boundary tone $(\mathrm{L} \%)$ as well as the rise-fall nuclear contour in NAmIce PQs.

(ii) Tonal events typical of NAmEngl PQs are found in NAmIce PQs, too. In particular, I predict that compared with IceIce PQs, the high boundary tone $(\mathrm{H} \%)$ and the low-rise nuclear contour feature more prominently in NAmIce PQs.

(iii) Since interference between an HL and a dominant language has been shown to be bidirectional, I predict that compared with NAmEngl PQs produced by speakers without Icelandic background, the NAmEngl PQs produced by speakers with a NAmIce background contain more intonational features typical of Icelandic PQs (that is, L\%, nuclear rise-fall).

First, features typical of IceIce PQs can also be found in NAmIce PQs (prediction i). In particular, the low boundary tone (L\%) is found in NAmIce PQs in $40 \%$ of all cases, a figure significantly higher than in NAmEngl PQs (17\%). Even though these results contrast with the $86.8 \%$ occurrence of L\% in IceIce PQs (the difference also being statistically significant), it is remarkable that falling PQs can be found in NAmIce to such an extent, given that for decades, the dominant language of all the NAmIce speakers in the study has been NAmEngl.

Similarly, the default nuclear contour of IceIce PQs, the rise-fall, also reaches considerable numbers $(32.5 \%)$ in NAmIce PQs. Moreover, the remaining falls belong to the category of high-falls $(7.5 \%$ in NAmIce PQs), which is also the second most frequent pattern in IceIce PQs. These results are in line with the assumption that prosodic features are persistent in the phonological system of languages in contact situations (for example, Mackey 2000:48). NAmIce, which is the L1 for all the NAmIce speakers and the only L1 for most speakers (i.e., for the sequential bilinguals, recall that two speakers were simultaneous bilinguals), has been in contact with NAmEngl for decades, and NAmEngl has been the dominant language for all the NAmIce speakers for a very long time. The results are also in line with Queen's (2001:67) idea that the maintenance of specific prosodic structures may be linked to 
specific morphosyntactic forms, and that interrogatives are a case in point. Moreover, the results lend support to Robles-Puente's (2014) finding that heritage speakers retain intonational features of their L1, that is, their HL.

Second, tonal events typical of NAmEngl PQs were found in NAmIce PQs, too, to a considerable extent (prediction ii). Specifically, this concerns the presence of $\mathrm{H} \%$, as well as the most typical nuclear contour in NAmEngl PQs: the low-rise (for example, Pierrehumbert \& Hirschberg 1990, Bartels 1999, Hedberg et al. 2017; see section 2 above). The prediction that both the rise to $\mathrm{H} \%$ and the specific nuclear accent low-rise are used in NAmIce PQs to a considerable extent is also borne out. The final rise to $\mathrm{H} \%$ (60\% of NAmIce PQs) and the low-rise (56.6\% of NAmIce PQs) are the most frequent patterns in NAmIce PQs, although clearly - and statistically significantly so - not to the same extent as in NAmEngl PQs. Thus, one finds the use of NAmEngl intonational features in NAmIce, in addition to typical IceIce features. I interpret this finding as an interference effect, such that features belonging to one language are used while speaking the other (Mackey 2000). In NAmIce, the relevant features (final rise to $\mathrm{H} \%$, low-rise nuclear contour) are used in the same environment as the corresponding IceIce intonational features, namely, in information-seeking PQs. They do not fully replace the IceIce features, but are used alongside them in an almost balanced distribution. These findings are in line with Bullock 2009 that finds features typical of NAmEngl intonation in moribund Frenchville French.

Notice, however, that given the use of IceIce features in NAmIce PQs, these results cannot be fully interpreted along the lines of Bullock's (2009) prosodic calquing, because the low-rise also occurs in $10.6 \%$ of the IceIce PQs $(\mathrm{N}=16)$, and there are $13.2 \%$ rises $(\mathrm{H} \%$; $\mathrm{N}=20)$ altogether. Therefore, phonologically speaking, the rise cannot be interpreted as a feature recruited from NAmEngl. Rather, the frequency of $\mathrm{H} \%$ and the extension of its use beyond special connotations can be argued to be due to the influence of NAmEngl on NAmIce. The results are in line with Robles-Puente 2014, which finds features typical of Los Angeles English intonation in heritage Spanish spoken in Los Angeles.

Third, there is a tendency for NAmEngl PQs produced by speakers with a NAmIce background to contain more intonational features typical of Icelandic PQs than NAmEngl PQs produced by speakers without 
Icelandic background (prediction iii), even though this difference is not significant. Here I return to the intonational patterns given in table 1, section 5.1: NAmEngl versus NAmEngl-csw. What is particularly noteworthy is the difference in the frequency of the rise $(\mathrm{H} \%)$ between the two groups (NAmEngl: $89.5 \%$; NAmEngl-csw: 78.6\%). While this difference is statistically not significant, it does suggest that the Icelandic intonation system, which typically has falling PQs, influences the NAmEngl of the NAmIce speakers. This influence is in line with Huffines' (1986) finding that certain prosodic features of the dominant language (NAmEngl) as spoken by heritage speakers of another language (NAmIce in the present study, PG in Huffines' study) may result from the influence of the $\mathrm{HL}$ on the dominant language. It is also in line with Robles-Puente (2014), who finds that heritage speakers of Spanish transfer certain intonational features specific to Spanish to their L2, Los Angeles English.

In sum, all three predictions have been borne out, although the results concerning prediction (iii) are statistically not significant. Therefore, they should be considered a tendency, which could possibly be strengthened by increasing the number of tokens. Thus, taken together, the results of the present study add to the evidence for bidirectional interference in intonation between an HL (here NAmIce) and the dominant language (here NAmEngl).

Two further points deserve discussion. The first concerns the use of the rise-fall nuclear contour in IceIce versus NAmIce PQs (final comparison in section 5.2, table 10), and specifically the use of the bitonal rising nuclear accent $(\mathrm{L}+\mathrm{H})$. The comparison between the nuclear rises in the two Icelandic varieties revealed the following differences. Nuclear rises in IceIce typically have early peaks, that is, the rise is completed within the nuclear syllable $\left(\mathrm{L}+\mathrm{H}^{*}\right)$. By contrast, the distribution is almost balanced in NAmIce, with slightly more late peaks $\left(\mathrm{L}^{*}+\mathrm{H}\right)$ than early peaks $\left(\mathrm{L}+\mathrm{H}^{*}\right.$; see table 10$)$. The difference turned out to be statistically significant. The late peak rise $\left(\mathrm{L}^{*}+\mathrm{H}\right)$, however, has been argued by Árnason $(1998,2005,2011)$ to be the default nuclear pitch accent in IceIce PQs (see section 2 above). In his account, IceIce PQs differ from declaratives in that the latter typically have $\mathrm{H}^{*}$ pitch accents. In the present analysis, the difference between $\mathrm{L}^{*}+\mathrm{H}$ and $\mathrm{L}+\mathrm{H}^{*}$ is a phonetic difference in the exact timing of the rise and peak. In particular, following Dehé 2010, nuclear rises were annotated $\mathrm{L}+\mathrm{H}^{*}$ if $\mathrm{H}$ 
was aligned within the nuclear syllable (typically, within the vowel in open CV: syllables, and in the final consonant (cluster) in closed CVC. syllables). However, note that peak alignment must generally be seen as gradual rather than categorical (for discussion, see Arvaniti et al. 2000, Atterer \& Ladd 2004, as well as Dehé 2010 for IceIce, among others). Thus, both $\mathrm{L}^{*}+\mathrm{H}$ and $\mathrm{L}+\mathrm{H}^{*}$ are described here as nuclear rises.

As far as the distinction between nuclear accents in PQs versus declaratives is concerned, $\mathrm{H}$ alignment in most IceIce PQs in the present data set is very similar to peak alignment in declarative nuclear accents as reported in Dehé's (2010) study on peak alignment in IceIce declaratives. These results seem to go against Árnason's assumptions about nuclear accents in IceIce PQs (late rise) versus declaratives (early rise). However, Árnason's analysis of nuclear rises was guided by (his own) perception, and a systematic comparison between the phonetics of nuclear pitch accents in declaratives versus PQs in IceIce has yet to be made. Moreover, future research will have to reveal further differences between the intonational contours of questions versus declaratives in, for example, the prenuclear region (see Petrone \& Niebuhr 2014 for German, among others), both in production and in perception.

Two possible explanations for the significant difference between the rises produced by IceIce and NAmIce speakers come to mind. First, there may be a change in intonational features: The IceIce nuclear PQ accent is shifting gradually from late to early peak, whereas the NAmIce nuclear PQ accent is not shifting, but the late peak is maintained. However, given the age of the IceIce speakers included in the present study, this explanation would not be compatible with Árnason's (1998, 2005, 2011) observations concerning late peaks in $\mathrm{PQs}$ in present-day IceIce. A comparison between different age groups would provide more information about this contrast.

A second option is that the (late) rise produced by the NAmIce speakers is due to influence from NAmEngl. Recall that the most frequent contour in NAmEngl PQs is the low-rise $\mathrm{L}^{*} \mathrm{H}-\mathrm{H} \%$, that is, a rise leading to a peak even later in the utterance. The high tone following $\mathrm{L}^{*}$ is analyzed not as a trailing tone, which is part of the nuclear pitch accent, but as a phrasal edge tone. If this accent type gradually influences the NAmIce nuclear rise, then the peak in NAmIce nuclear PQ accents may be reached later than in IceIce, but not as late as in NAmEngl; this peak is then followed in NAmIce by a fall terminating in $\mathrm{L} \%$. These 
options will have to be addressed in research that would consider earlier recordings, and ideally, if at all possible, later recordings, too.

In any case - and this leads me to the second point yet to be discussed - a longitudinal study could add evidence. Although I detailed above why it is reasonable to assume that IceIce has not changed too much since the time of emigration, one cannot exclude the possibility that the intonation of PQs around 1900 was different from the one found in the IceIce group tested in this study. If the intonational features of IceIce PQs have changed since the 1900s, this could explain the difference in the rise between the two Icelandic varieties. Moreover, it is important to keep in mind that the current study (as well as previous studies on the intonation of HLs) represents just one point in time. A longitudinal study would reveal how intonational features develop in NAmIce. For example, it is conceivable that over time, NAmEngl features become more dominant, and while Icelandic features persist, they may become less frequent. Recordings of earlier stages of NAmIce do exist (for example, Bessason's 1967 interviews recorded in the 1960s and Arnbjörnsdóttir's 2006 interviews recorded in the 1980s), and they can hopefully be used for comparison in future research. Another group the current data will have to be compared with include speakers of Icelandic who have immigrated to English-speaking countries more recently and are now first- or second- generation immigrants, that is, more recent heritage speakers.

Building on previous approaches to periods of L1 acquisition, Benmamoun et al. (2013:139) present two hypotheses relating to linguistic acquisition in sequential bilinguals. They argue that heritage speakers whose L1 was the HL (here NAmIce) and whose L2 became the dominant and thus the primary language at some point during childhood (here NAmEngl) would provide a particularly valuable testing ground for these hypotheses. The first is the permanence hypothesis, according to which "once commitment has taken place" during the childhood period of acquisition, the cognitive "resources dedicated to the original language cannot be reassigned, and the relevant knowledge persists throughout life." The second hypothesis, the contingency hypothesis, maintains that "reorganization of the resources can occur" if the input of L1 ceases and the child is exposed to another language. The authors argue that results of previous phonological studies focusing on phonemic contrasts support the permanence hypothesis. The results of the current study, which tested 
the intonational patterns produced by NAmIce speakers, may also be interpreted in such a way that they lend support to the permanence hypothesis, given that NAmIce speakers frequently use intonational categories typical of IceIce.

\section{Conclusion.}

To conclude, focusing on intonation, the present study adds to the evidence for (bidirectional) interference between an HL (here moribund NAmIce) and the dominant language (here NAmEngl). In particular, I interpret the considerable presence of intonational features typical of IceIce PQs in NAmIce PQs as a maintenance effect, which supports the view that prosodic features are persistent in HLs. Moreover, I interpret the considerable presence of intonational features typical of NAmEngl PQs in NAmIce PQs as evidence for transfer of certain features from the dominant language to the HL. While the present results are fully in line with the observation that interference between an HL and a dominant language is bidirectional, the way that NAmIce influences NAmEngl will have to be studied more carefully and with more data. Future research, in particular, research using existing recordings from earlier stages of NAmIce, as well as research including recent Icelandic immigrants to North America and more generally bilingual Icelandic speakers, may reveal more insights on intonational development in HLs. 
APPENDIX

\begin{tabular}{|c|c|c|c|c|}
\hline ڤ̈ & $\frac{\stackrel{U}{\tilde{I}}}{\stackrel{\Xi}{\Xi}}$ & 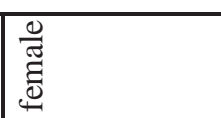 & 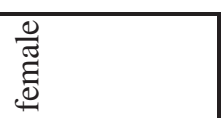 & 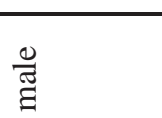 \\
\hline 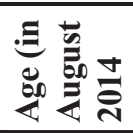 & g) & $\infty$ & 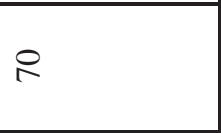 & $\mathbb{N}$ \\
\hline 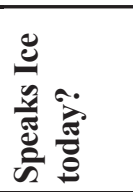 & ‡ & 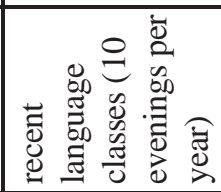 & \& & @ \\
\hline 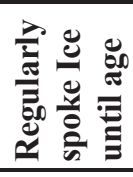 & 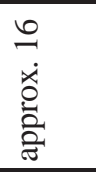 & त & $\approx$ &  \\
\hline $\begin{array}{l}\frac{8}{0} \\
\frac{\pi}{2} \\
\frac{0}{2}\end{array}$ & 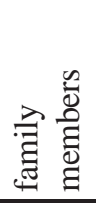 &  & 离岕 & 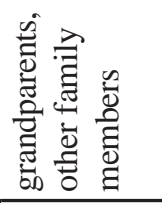 \\
\hline 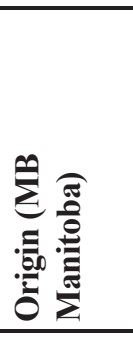 & 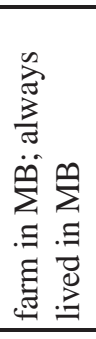 & 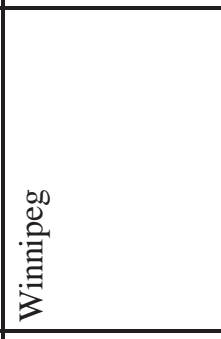 & 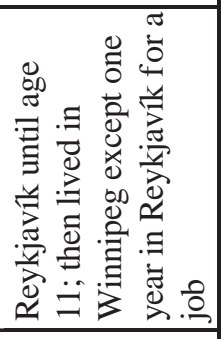 & 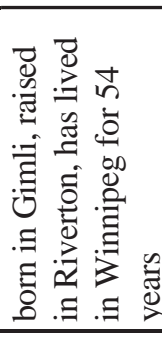 \\
\hline 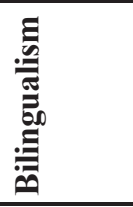 & 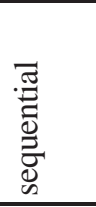 & 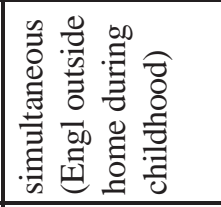 & 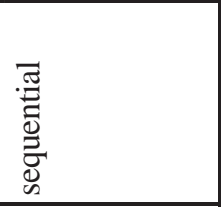 & 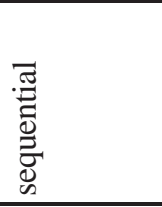 \\
\hline $\mathcal{~ ב ~}$ & 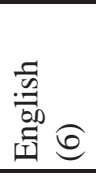 & 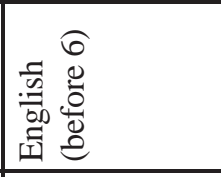 & $\begin{array}{l}\frac{5}{6} \\
: 00 \\
\text { 馬 }\end{array}$ &  \\
\hline$\exists$ & 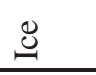 & $\stackrel{.}{.}$ & $\stackrel{\Xi}{.}$ & $\stackrel{\circlearrowright}{\circlearrowright}$ \\
\hline 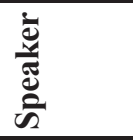 & $\overrightarrow{0}$ & 客 & $\hat{\jmath}$ & $\sum^{\infty}$ \\
\hline
\end{tabular}




\begin{tabular}{|c|c|c|c|c|c|c|}
\hline ڤँ & 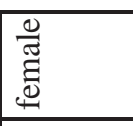 & 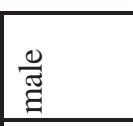 & $\begin{array}{l}\frac{0}{\tilde{J}} \\
\underline{\Xi} \\
\end{array}$ & 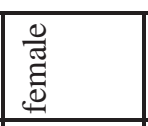 & 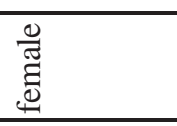 & 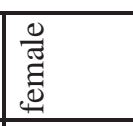 \\
\hline  & t & $\infty$ & $\cong$ & $\infty$ & 2 & $\mathbb{N}$ \\
\hline 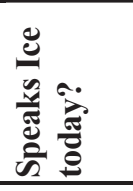 & 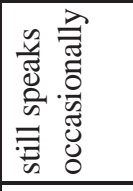 & 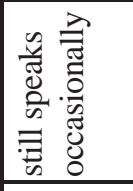 & 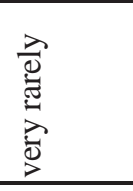 & 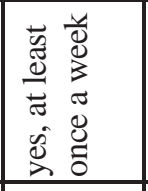 & 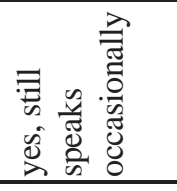 & 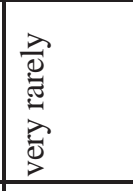 \\
\hline 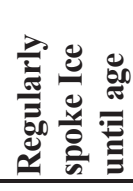 & 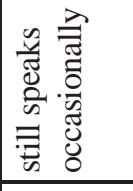 & 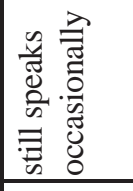 & 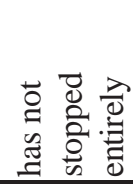 & 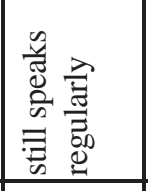 & 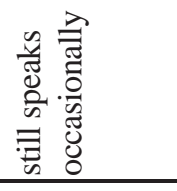 & 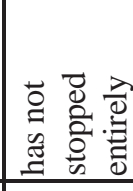 \\
\hline $\begin{array}{l}\frac{8}{0} \\
\frac{0}{0} \\
\frac{0}{2}\end{array}$ & 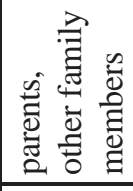 & 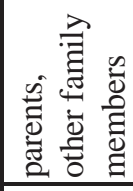 & 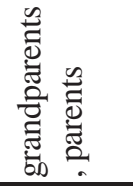 & 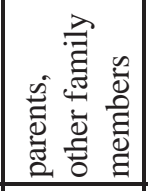 & 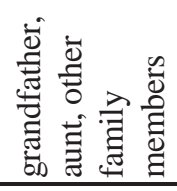 & 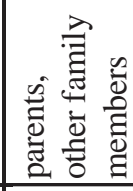 \\
\hline 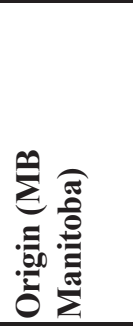 & : & \begin{tabular}{|l}
$\dot{\bar{E}}$ \\
\end{tabular} &  & \begin{tabular}{|l}
$: \bar{\xi}$ \\
:
\end{tabular} & 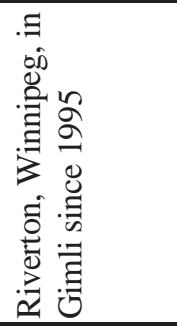 & 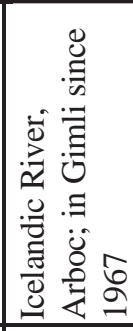 \\
\hline 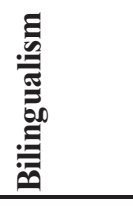 & 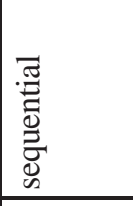 & 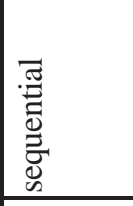 & 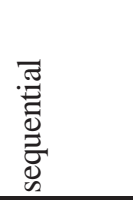 & 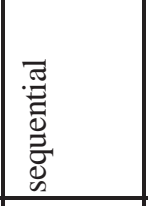 & 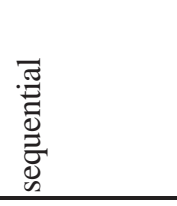 & 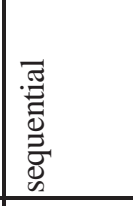 \\
\hline 工 & 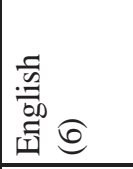 & 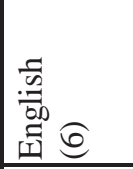 & 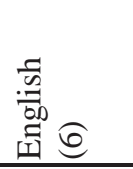 & 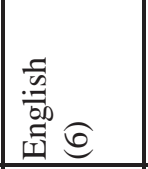 &  & 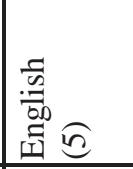 \\
\hline$\Xi$ & $\ddot{~}$ & 苂 & $\stackrel{\mathscr{0}}{0}$ & $\stackrel{0}{0}$ & $\stackrel{\mathscr{O}}{0}$ & $\stackrel{0}{0}$ \\
\hline  & $\begin{array}{l}\overline{0} \\
0 \\
\end{array}$ & $\begin{array}{l}\text { ठิ } \\
\text { U }\end{array}$ & రీ & \begin{tabular}{|l} 
\\
0 \\
0 \\
0
\end{tabular} &  & $\begin{array}{l}8 \\
0 \\
0\end{array}$ \\
\hline
\end{tabular}




\begin{tabular}{|c|c|c|c|c|c|}
\hline$\ddot{\vec{D}}$ & 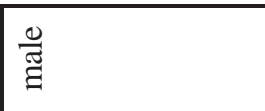 & 总 &  & $\frac{\stackrel{0}{\overparen{\Xi}}}{\Xi}$ & 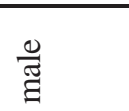 \\
\hline 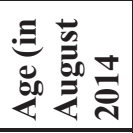 & $\infty$ & 2 & $\mathbb{N}$ & $\stackrel{\infty}{\sim}$ & $\underset{\infty}{+}$ \\
\hline 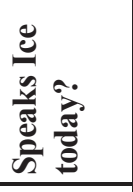 & 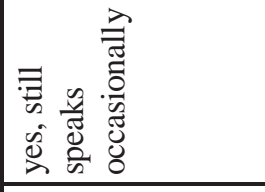 & 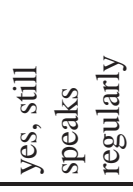 & 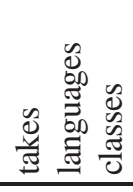 & @ & 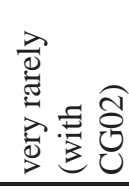 \\
\hline 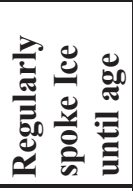 & 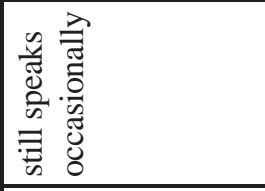 &  & 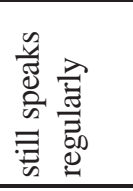 & 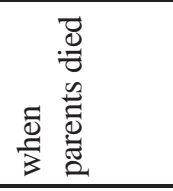 & 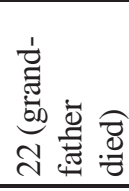 \\
\hline $\begin{array}{l}\frac{\pi}{0} \\
\frac{0}{0} \\
0 \\
\frac{0}{0} \\
\frac{0}{2} \\
\end{array}$ & 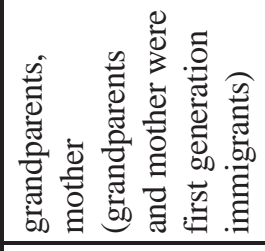 & 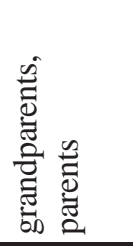 & 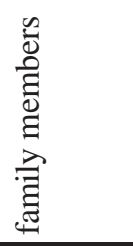 & 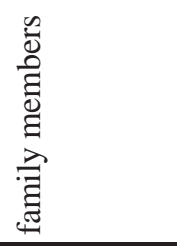 & 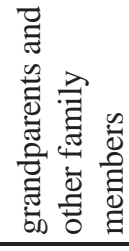 \\
\hline 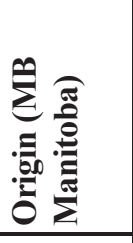 & 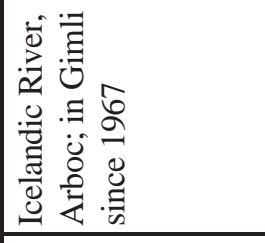 & 司 & 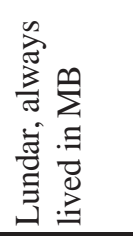 & 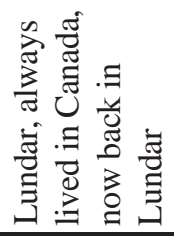 & 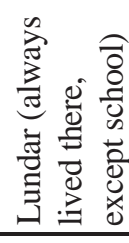 \\
\hline 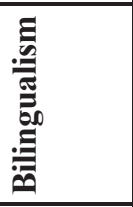 & 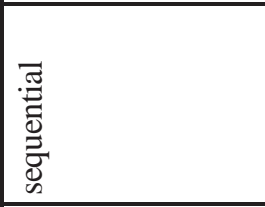 & 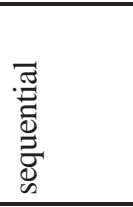 & 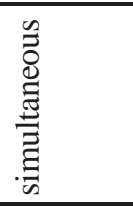 & 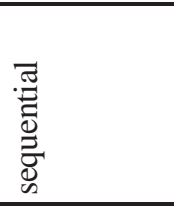 & 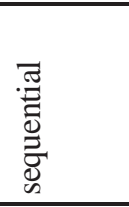 \\
\hline $\mathcal{~}$ & 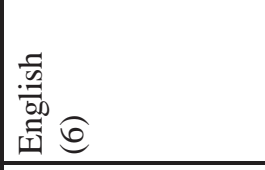 & 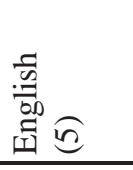 & $\stackrel{8}{.}$ & 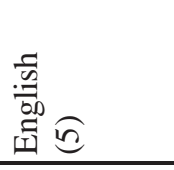 & 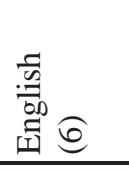 \\
\hline$\Xi$ & 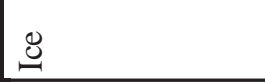 & $\stackrel{\circlearrowright}{.}$ & $\begin{array}{l}\overline{50} \\
\text { 馬 }\end{array}$ & 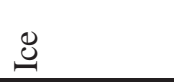 & $\underset{ٍ}{\ddot{\theta}}$ \\
\hline 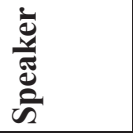 & 令 & 㐫 & $\stackrel{\bar{\sigma}}{\sigma}$ & తి & 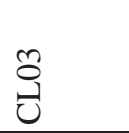 \\
\hline
\end{tabular}




\section{REFERENCES}

Anderson, Anne H., Miles Bader, Ellen Gurman Bard, Elizabeth Boyle, Gwyneth Doherty, Simon Garrod, Stephen Isard, Jacqueline Kowtko, Jan McAllister, Jim Miller, Catherine Sotillo, Henry S. Thompson, Regina Weinert. 1991. The HCRC map task corpus. Language and Speech 34. 351366.

Árnason, Kristján. 1985. Icelandic word stress and metrical phonology. Studia Linguistica 39. 93-129.

Árnason, Kristján. 1987. The stress of prefixes and suffixes in Icelandic. Nordic Prosody IV, ed. by Kirsten Gregersen \& Hans Basbøll, 137-146. Odense: Odense University Press.

Árnason, Kristján. 1998. Toward an analysis of Icelandic intonation. Nordic Prosody. Proceedings of the VIIth Conference, Joensuu 1996, ed. by Stefan Werner, 49-62. Frankfurt am Main: Peter Lang.

Árnason, Kristján. 2005. Hljóð. Handbók um hljóðfrceði og hljóðkerfisfrceði, vol. 1. Bindi. Reykjavík: Almenna bókafélagið.

Árnason, Kristján. 2011. The phonology of Icelandic and Faroese. Oxford: Oxford University Press.

Arnbjörnsdóttir, Birna. 2006. North American Icelandic: The life of a language. Winnipeg, MB: University of Manitoba Press.

Arnbjörnsdóttir, Birna. 2015. Reexamining Icelandic as a heritage language in North America. Germanic heritage languages in North America: Acquisition, attrition and change, ed. by Janne Bondi Johannessen \& Joseph C. Salmons, 72-93. Amsterdam: John Benjamins.

Arvaniti, Amalia, D. Robert Ladd, \& Inke Mennen. 2000. What is a starred tone? Evidence from Greek. Papers in laboratory phonology V: Acquisition and the lexicon, ed. by Michael B. Broe \& Janet B. Pierrehumbert, 119-131. Cambridge: Cambridge University Press.

Atterer, Michaela, \& D. Robert Ladd. 2004. On the phonetics and phonology of "segmental anchoring" of F0: Evidence from German. Journal of Phonetics 32. 177-197.

Bartels, Christine. 1999. The intonation of English statements and questions. A compositional interpretation. New York, NY: Garland Publishing.

Bates, Douglas M., \& Deepayan Sarkar. 2007. Ime4: Linear mixed-effects models using S4 classes. R package version 0.9975-12.

Beckman, Mary E., Manuel Díaz-Campos, Julia Tevis McGory, \& Terrell A. Morgan. 2002. Intonation across Spanish, in the Tones and Break Indices framework. Probus 14. 9-36.

Beckman, Mary E., Julia Hirschberg, \& Stefanie Shattuck-Hufnagel. 2005. The original ToBI system and the evolution of the ToBI framework. Prosodic typology, ed. by Sun-Ah Jun, 9-54. Oxford: Oxford University Press. 
Benmamoun, Elabbas, Silvina Montrul, \& Maria Polinsky. 2013. Heritage languages and their speakers: Opportunities and challenges for linguistics. Theoretical Linguistics 39. 129-181.

Bergmann, Christopher, Amber Nota, Simone A. Sprenger, \& Monika S. Schmid. 2016. L2 immersion causes non-native-like L1 pronunciation in German attriters. Journal of Phonetics 58. 71-86.

Bessason, Haraldur. 1967. A few specimens of North American-Icelandic. Scandinavian Studies 39. 115-146.

Boersma, Paul. 2001. Praat, a system for doing phonetics by computer. GLOT International 5. 341-345.

Boersma, Paul, \& David Weenink. 2016. Praat: Doing phonetics by computer [Computer program]. Version 6.0.21. Available at http:/www.praat.org/.

Bullock, Barbara E. 2009. Prosody in contact in French: A case study from a heritage variety in the USA. International Journal of Bilingualism 13. 165194.

Burridge, Kate. 2007. Language contact and convergence in Pennsylvania German. Grammars in contact: A cross-linguistic typology, ed. by Alexandra Y. Aikhenvald \& R. M. W. Dixon, 179-200. Oxford: Oxford University Press.

Chang, Charles B., \& Yao Yao. 2016. Toward an understanding of heritage prosody: Acoustic and perceptual properties of tone produced by heritage, native, and second language speakers of Mandarin. Heritage Language Journal 13. 134-160.

Dehé, Nicole. 2010. The nature and use of Icelandic prenuclear and nuclear pitch accents: Evidence from F0 alignment and syllable/segment duration. Nordic Journal of Linguistics 33. 31-65.

Dehé, Nicole. 2015. The intonation of the Icelandic other-initiated repair expressoins Ha 'Huh' and Hvað segirðu/Hvað sagðirðu 'What do/did you say'. Nordic Journal of Linguistics 38. 189-219.

Einarsson, Stefán. 1973. Icelandic: Grammar, texts, glossary, 2nd edn. Baltimore, MD: The Johns Hopkins University Press.

Fletcher, Janet, \& Lesley Stirling. 2014. Prosody and discourse in the Australian map task corpus. The Oxford handbook of corpus phonology, ed. by Jacques Durand, Ulrike Gut, \& Gjert Kristoffersen, 562-575. Oxford: Oxford University Press.

Grice, Martine, Ralf Benzmüller, Michelina Savino, \& Bistra Andreeva. 1995. The intonation of queries and checks across languages: Data from map task dialogues. Proceedings of the XIIth International Congress of Phonetic Sciences: ICPhS 95, ed. by Kjell Elenius \& Peter Branderud, 648-651. Stockholm: KTH and Stockholm University. 
Grice, Martine, \& Michelina Savino. 2003. Map tasks in Italian: Asking questions about given, accessible and new information. Catalan Journal of Linguistics 2. 153-180.

Haugen, Einar. 1984. Die skandinavischen Sprachen. Hamburg: Buske. Hedberg, Nancy, Juan M. Sosa, \& Emrah Görgülü. 2017. The meaning of intonation in yes-no questions in American English: A corpus study. Corpus Linguistics and Linguistic Theory 13. 1-48.

Helgason, Pétur. 2006. SMTC-A Swedish map task corpus. Proceedings of FONETIK 2006 (Working Papers 52), ed. by Gilbert Ambrazaitis \& Susanne Schötz, 57-60. Lund: Centre for Languages and Literature, Lund University.

Henriksen, Carol, \& Johan van der Auwera. 1994. The Germanic languages. König \& van der Auwera 1994, 1-18.

Hoot, Bradley. 2012. Presentational focus in heritage and monolingual Spanish. Chicago, IL: University of Illinois at Chicago dissertation.

Huffines, Marion Lois. 1986. Intonation in language contact: Pennsylvania German English. Studies on the languages and the verbal behavior of the Pennsylvania Germans, ed. by Werner Enninger, 25-36. Stuttgart: Steiner.

Jaeger, T. Florian. 2008. Categorical data analysis: Away from ANOVAs (transformation or not) and towards Logit Mixed Models. Journal of Memory and Language 59. 434-446.

Johannessen, Janne Bondi, \& Joseph Salmons. 2015. The study of Germanic heritage languages in the Americas. Germanic heritage languages in North America: Acquisition, attrition and change, ed. by Janne B. Johannessen \& Joseph Salmons, 1-17. Amsterdam: John Benjamins.

König, Ekkehard, \& Johan van der Auwera (eds.). 1994. The Germanic languages. London: Routledge.

Kristinsson, Júníus. 1983. Vesturfaraskrá, 1870-1914; A record of emigrants from Iceland to America 1870-1914. Institute of History, Reykjavík: University of Iceland.

Kupisch, Tanja, Dagmar Barton, Katja Hailer, Ewgenia Klaschik, Ilse Stangen, Tatjana Lein, \& Joost van de Weijer. 2014. Foreign accent in adult simultaneous bilinguals. Heritage Language Journal 11. 123-150.

Kügler, Frank. 2004. Dialectal variation in question intonation in two German dialects: The case of Swabian and Upper Saxon. Language variation in Europe: Papers from the Second International Conference on Language Variation in Europe, ICLaVE 2, ed. by Angela Karstadt, Britt-Louise Gunnarsson, Lena Bergström, \& Gerd Eklund, 227-240. Uppsala: Department of Scandinavian Languages, Uppsala University.

Lickley, Robin J., Astrid Schepman, \& D. Robert Ladd. 2005. Alignment of "phrase accent" lows in Dutch falling rising questions: Theoretical and methodological implications. Language and Speech 48. 157-183. 
Lleó, Conxita, \& Martin Rakow. 2011. Intonation targets of yes/no questions by Spanish and German monolingual and bilingual children. The development of grammar: Language acquisition and diachronic change, ed. by Esther Rinke \& Tanja Kupisch, 263-286. Amsterdam: John Benjamins.

Mackey, William F. 2000. The description of bilingualism. The bilingualism reader, ed. by Li Wei, 26-54. London: Routledge.

Montrul, Silvina. 2016. The acquisition of heritage languages. Cambridge: Cambridge University Press.

Peters, Jörg. 2006. Intonation deutscher Regionalsprachen. Berlin: Walter de Gruyter.

Petrone, Caterina, \& Oliver Niebuhr. 2014. On the intonation of German intonation questions: The role of the prenuclear region. Language and Speech 57. 108-146.

Pierrehumbert, Janet, \& Julia Hirschberg. 1990. The meaning of intonational contours in the interpretation of discourse. Intentions in communication, ed. by Philip R. Cohen, Jerry Morgan, \& Martha E. Pollack, 271-311. Cambridge, MA: MIT Press.

Prieto, Pilar, Ana Estrella, Jill Thorson, \& Maria del Mar Vanrell. 2012. Is prosodic development correlated with grammatical and lexical development? Evidence from emerging intonation in Catalan and Spanish. Journal of Child Language 39. 221-257.

Prieto, Pilar, Jill Thorson, Ana Estrella, \& Maria Del Mar Vanrell. 2011. Early intonational development in Spanish: A case study. Selected proceedings of the 13th Hispanic Linguistics Symposium, ed. by Luis A. Ortiz-López, 203213. Somerville, MA: Cascadilla Proceedings Project.

Queen, Robin M. 2001. Bilingual intonation patterns: Evidence of language change from Turkish-German bilingual children. Language in Society 30. 5580 .

Robles-Puente, Sergio. 2014. Prosody in contact: Spanish in Los Angeles. Los Angeles, CA: University of Southern California dissertation.

Savino, Michelina. 2012. The intonation of polar questions in Italian: Where is the rise? Journal of the International Phonetic Association 42. 23-48.

Sekerina, Irina A., \& John C. Trueswell. 2011. Processing of contrastiveness by heritage Russian bilinguals. Bilingualism: Language and Cognition 14. 280300 .

Silverman, Kim, Mary Beckman, John Pitrelli, Mari Ostendorf, Colin Wightman, Patti Price, Janet Pierrehumbert, \& Julia Hirschberg. 1992. ToBI: A standard for labeling English prosody. Proceedings of the 1992 International Conference on Spoken Language Processing, ed. by John J. Ohala, 867-870. Edmonton, AB: University of Alberta.

Stangen, Ilse, Tanja Kupisch, Anna Lia Proietti Ergün, \& Marina Zielke. 2015. Foreign accent in heritage speakers of Turkish in Germany. Transfer effects in 
multilingual language development, ed. by Hagen Peukert, 87-107.

Amsterdam: John Benjamins.

Stefánsson, Vilhjálmur. 1903. English loan-nouns used in the Icelandic colony of North Dakota. Dialect Notes, vol. II, 354-362. New Haven, CT: The American Dialect Society.

Thorson, Jill, Joan Borras-Comes, Verònica Crespo-Sendra, Maria del Mar Vanrell, \& Pilar Prieto. 2015. The acquisition of melodic form and meaning in yes-no interrogatives by Catalan and Spanish speaking children. Probus 27. 73-99.

Thráinsson, Höskuldur. 1994. Icelandic. König \& van der Auwera 1994, 142189.

Thráinsson, Höskuldur. 2007. The syntax of Icelandic. Cambridge: Cambridge University Press.

Thráinsson, Höskuldur. 2016. Incomplete acquisition and language attrition in different settings. Paper presented at the Thirty Eighth Annual Conference of the German Linguistics Society (DGfS), held at University of Konstanz, February 24-26, 2016.

Thráinsson, Höskuldur, \& Kristján Árnason. 1992. Phonological variation in 20th-century Icelandic. Íslenskt mál 14. 89-128.

Universität Konstanz

Fachbereich Sprachwissenschaft

Fach 186

78457 Konstanz

Germany

[nicole.dehe@uni-konstanz.de] 